\title{
REVIEW
}

\section{Reproduction by Fragmentation in Corals}

\author{
Raymond C. Highsmith* \\ Smithsonian Tropical Research Institute, Box 2072, Balboa, Panama \\ and \\ Department of Zoology, University of Washington, Seattle, Washington 98195, USA
}

\begin{abstract}
Production of new colonies by fragmentation of established colonies is shown to be an extremely important mode of reproduction and local distribution among major reef-building corals. This type of reproduction avoids the high mortality rates of larvae and juveniles and spreads the risk of mortality for the genotype. Fragmentation by corals with high growth rates results in their domination of certain reef zones, rapid growth of reefs on which these corals are abundant, and rapid recovery from disturbances. I conclude that a number of the most successful corals are adapted to fragment, i.e. have incorporated fragmentation into their life histories.
\end{abstract}

\section{INTRODUCTION}

Fragmentation of a single colony into 2 or more colonies appears to be the predominant mode of reproduction in certain corals and an important mode in others (Table 1). All of the coral species listed in Table 1 and discussed below are, ecologically and geologically, important members of their respective reef communities, with Acropora cervicornis, A. palmata and Montastrea annularis most often listed as the major reef-building corals in the Caribbean, Pocillopora damicornis the most important in the eastern Pacific,

\footnotetext{
- Present address: Friday Harbor Laboratories, University of Washington, Friday Harbor, Washington 98250, USA

- Caribbean: Lewis (1960); Mesolella (1967); Glynn (1973); Goreau and Goreau (1973); Milliman (1973); Scatterday (1974); Adey (1975); Bak (1976, 1977); Macintyre and Glynn (1976); Shinn (1976); Bonem and Stanley (1977); Lighty (1977); Macintyre et al. (1977); Focke (1978); Gladfelter et al (1978); Rogers (1979); Brown and Dunne (1980).

Eastern Pacific: Squires (1959); Glynn et al. (1972); Porter (1972); Glynn and Macintyre (1977); Glynn et al. (1979) Indo-West Pacific: Wells (1954); Talbot (1965); Braithwaite (1971); Davies et al. (1971); Loya and Slobodkin (1971); Mergner (1971); Pichon (1971); Rosen (1971); Maragos (1972); Stoddart (1973); Dollar (1975); Chevalier (1977); Pichon (1977); Salvat et al. (1977); Scoffin (1977a, b); Ditlev (1978); Sheppard $(1979,1980 a)$
}

and members of the Acroporidae and Poritidae of primary importance in the Indo-West Pacific $*$. These corals may all reproduce sexually as well as by fragmentation, but in general their local abundance and distribution on reefs appear to be due largely to the latter.

I define 'fragment' as a live portion of a coral colony that has become physically separated, due to the breakage of the skeleton, from the rest of the colony. The special case where the live surface of a coral becomes divided into 2 or more sections without breakage of the skeleton will be dealt with separately. Following Connell (1973), I consider a colony to be an individual; asexual reproduction in corals as used in this paper refers strictly to an increase in number of independent colonies rather than to growth of a single colony by budding new polyps. I treat colonies as individuals because they (1) recruit as individuals; (2) do not reproduce sexually until the colony has reached a certain size or age (Connell, 1973; Stimson, 1978); (3) often have characteristic growth forms for each species and in some cases even repair damage so as to restore the original colony shape (Stephenson and Stephenson, 1933; Loya, 1976a) suggesting integration of activities; (4) translocate materials within the colony (Pearse and Muscatine, 1971; Taylor, 1977); and (5) the ecologically relevant mortality rate is that for entire colonies 
Table 1 Corals reported to reproduce by fragmentation

\begin{tabular}{|c|c|c|c|}
\hline Species & Family & Growth form & Source \\
\hline \multicolumn{4}{|l|}{ Caribbean } \\
\hline Acropora palmata & Acroporidae & Branching & $\begin{array}{l}\text { Bak and Engel (1979) } \\
\text { Highsmith et al. (1980) }\end{array}$ \\
\hline Acropora cervicornis & Acroporidae & Branching & $\begin{array}{l}\text { Gilmore and Hall (1976) } \\
\text { Shinn (1976) } \\
\text { Tunnicliffe }(1978,1980)\end{array}$ \\
\hline Madracis mirabilis & Pocilloporidae & Branching & Bak and Engel (1979) \\
\hline Porites furcata & Poritidae & Branching & This paper \\
\hline Montastrea annularis & Favijdae & Massive & Jones (1977) \\
\hline \multicolumn{4}{|l|}{ Eastern Pacific } \\
\hline Pocillopora damicornis & Pocilloporidae & Branching & $\begin{array}{l}\text { Glynn (in press) } \\
\text { Wellington (1981) }\end{array}$ \\
\hline Pavona clavus & Agariciidae & Massive & This paper \\
\hline \multicolumn{4}{|l|}{ Indo-West Pacific } \\
\hline Acropora aspera & Acroporidae & Branching & Birkeland et a1. (1979) \\
\hline Acropora acuminata & Acroporidae & Branching & Randall (1973a) \\
\hline Acropora formosa & Acroporidae & Branching & $\begin{array}{l}\text { Grassle (1973) } \\
\text { Sheppard (1981) }\end{array}$ \\
\hline Acropora hyacinthus & Acroporidae & Branching & $\begin{array}{l}\text { Grassle (1973) } \\
\text { Sheppard (1981) }\end{array}$ \\
\hline Montipora sp. & Acroporidae & Various & Grassle (1973) \\
\hline Porites compressa & Poritidae & Branching & $\begin{array}{l}\text { Maragos (1972) } \\
\text { Dollar }(1975)\end{array}$ \\
\hline Porites lobata & Poritidae & Massive & Dollar (1975) \\
\hline Porites lutea & Poritidae & Massive & Highsmith (1980) \\
\hline Goniopora stokesi & Poritidae & Massive & Rosen and Taylor (1969) \\
\hline All family members & Fungiidae & Solitary & Wells (1966) \\
\hline
\end{tabular}

After considering a theoretical basis for the evolution of fragmentation, I summarize the growing evidence for the importance of this type of asexual reproduction in corals, relate life-history characteristics of fragmenting corals to predictions of the theory, and briefly discuss the ecological and geological consequences of coral reproduction by fragmentation.

\section{THEORETICAL BASIS FOR THE EVOLUTION OF FRAGMENTATION}

Possibly fragmentation is an inevitable consequence of being a relatively large, sessile organism, with a calcareous skeleton, and living in shallow marine environments; portions of colonies are simply broken off or separated from the rest of the colony by physical factors - such as currents or storms - and biologica] factors - such as predators or bioeroders. Alternatively, fragmentation in corals may be adaptive, i.e. selected for over evolutionary time and incorporated into the life history of many corals. I will attempt to demonstrate the validity of the latter hypothesis by comparing morphological features, habitat requirements, and life- history characteristics of corals that commonly fragment and those that do not.

\section{Definitions and Hypotheses}

$$
\text { Morphology }
$$

If fragmentation is not adaptive, then breakage is an injury and corals should have evolved growth forms that reduce the probability of such damage. Thus, corals should tend to have compact growth forms with low profiles or small adult sizes (determinate growth), low-porosity ( $\approx$ high-strength) skeletons, and maintain live tissue over all parts of the skeleton to prevent invasion and weakening of the skeleton by boring organisms. Conversely, if fragmentation is adaptive, those corals in which it occurs should have a more diverse array of growth forms and should have evolved skeletal features such that fragmentation is likely to occur at some frequency related to the probability of survival of the fragments. In this case, corals should have large colonies with relatively high profiles and have skeletal strengths commensurate with growth form, characteristic wave or current stress encoun- 
tered, and propensity to fragment. The combination of growth form, growth rate, and skeletal strength within a species should be such that fragmentation produces new colonies of a shape or size likely to survive. In this respect, regularly occurring structural weak points in the skeleton that increase the probability of breakage at those particular points, e.g. constrictions, regions of high porosity, systematic failure to maintain live tissue over (to prevent invasion by boring organisms) and enlarge skeletal zones likely to be mechanically stressed such as branch stems and column bases, or growth to the point of mechanical instability, will be considered as evidence that fragmentation has been selected for in a species.

The size and number of fragments produced by a coral colony are not independent and can be thought of as a continuum. Conceivably, corals could achieve a given level of asexual reproductive success by either producing many small fragments, each with a low probability of survival or a few large, highly viable fragments. Also, fragmenting corals should generally allocate little energy to maintaining live tissue over the entire skeleton for the purpose of excluding bioeroders since skeletal weak points may be inconsequential or even beneficial.

\section{Habitats}

If fragmentation is not adaptive, other factors being equal, then corals should occur in locations normally protected from strong currents and wave action in geographic locations seldom affected by storms, have life expectancies less than the average storm frequency, or reproduce at an early age. On the other hand, corals adapted to fragment, should have less restricted habitat requirements and life history features with respect to currents and storms. In fact, storms may indeed be major reproductive events for longlived corals, provided they are not so severe as to kill the resulting fragments.

\section{Life Histories}

For organisms that have incorporated both sexual and asexual reproduction into their life histories, Williams (1975) listed several expected differences between offspring produced by each method (Table 2 ). For sessile, colonial organisms, he specifically proposed the Strawberry-Coral Model in which organisms reproduce vegetatively to form colonies that spread until their tolerance limits are met. Since these colonies are inevitably mortal, sexual reproduction serves for dispersal to other locations. Although Williams
Table 2. Expected differences between asexually and sexually produced offspring. Adapted from Williams (1975)

\begin{tabular}{|ll|}
\hline Asexual offspring & Sexual offspring \\
\hline Large initial size & Small \\
Produced continuously & Seasonally limited \\
Develop close to parent & Widely dispersed \\
Develop immediately & Dormant \\
Develop directly to adult & Develop through a series of \\
stage & diverse embryos and \\
Environment and optimum & Environment and optimum \\
genotype predictable & genotype unpredictable \\
from those of parent & High mortality rate \\
Low mortality rate & \\
\hline
\end{tabular}

considered growth of coral colonies by production of new polyps to be asexual reproduction, I will relate the predictions in Table 2 and the Strawberry-Coral model to life-history traits associated with reproduction by fragmentation as one test of the hypothesis that fragmentation has been acted upon by natural selection and become incorporated into the life histories of certain corals.

Within a species, success of asexual reproduction should enhance sexual reproductive success but not vice versa. High growth rates, for example, could be selected for because individuals that grow fastest produce the largest number of asexual offspring resulting in both greater sexual output per unit time and longer life-span (see next paragraph) in which to reproduce. Conversely, those species that reproduce primarily sexually should develop features likely to further enhance sexual output such as reproducing at a younger age or producing more gametes at the expense of growth and maintenance (Harrigan, 1972), thus reducing the probability of fragmentation.

Mortality rates for clones, i.e. the original colony plus asexual offspring, should be considerably lower than for single colonies. If a colony is physically stressed, diseased (Antonius, 1977; Dustan, 1977), comes into contact with a superior competitor (Vicente, 1978), or is discovered by a predator (Endean, 1973; Glynn, 1976), the entire colony may be killed. If a colony has fragmented, however, the probability of mortality is independent for each fragment (to the same extent that it is for unrelated colonies of a species at a given

\footnotetext{
- Within a species, the larger the surface area, the greater the number of polyps in a colony and hence, the more gametes or larvae produced (Maragos, 1972). Over time, the surface area and number of polyps on 2 or more colonies should be greater than that of a single colony because of the restrictions imposed by colony shape, i.e. there is only space for a certain number of branches per colony, space competitors, available substratum, or proximity to the water surface
} 
location). For example, using an annual mortality rate of $3 \%$, the joint probability of mortality for a parent plus 1 large fragment would be $(0.03)^{2}$, for a parent plus 2 large fragments $(0.03)^{3}$, and so forth ${ }^{\circ}$. Clearly, many combinations of fragment number and mortality rate are possible but the probability of genotype mortality must nearly always be less when there are 2 or more separate colonies, even if the probability of mortality per individual increases temporarily as a result of division of 1 large colony into several smaller colonies. Connell (1973) found mortality rates declined sharply with increasing colony size for very small colonies, but colonies with a surface area $\geqslant 81 \mathrm{~cm}^{2}$ had an average mortality rate under $3 \%$ per year. Consequently, continued growth of large colonies can reduce their mortality rate no more than $3 \%$ (Fig. 1) and, in addition, breakage of large colonies may not result in any appreciable increase in mortality rate for them or their fragments if their size remains to the right of the inflection point on the mortality rate curve. These calculations lead to the prediction that species already having low mortality rates per colony would gain the most by fragmentation which, therefore, should be most common among long-lived species. For example, a colony with an annual probability of mortality of 0.10 would achieve a 10 -fold reduction in the genotype mortality rate by producing 1 additional colony via fragmentation, but a coral with a probability of mortality of 0.05 would reduce the genotype mortality rate by a factor of 20 . In addition, colonies derived from frag-

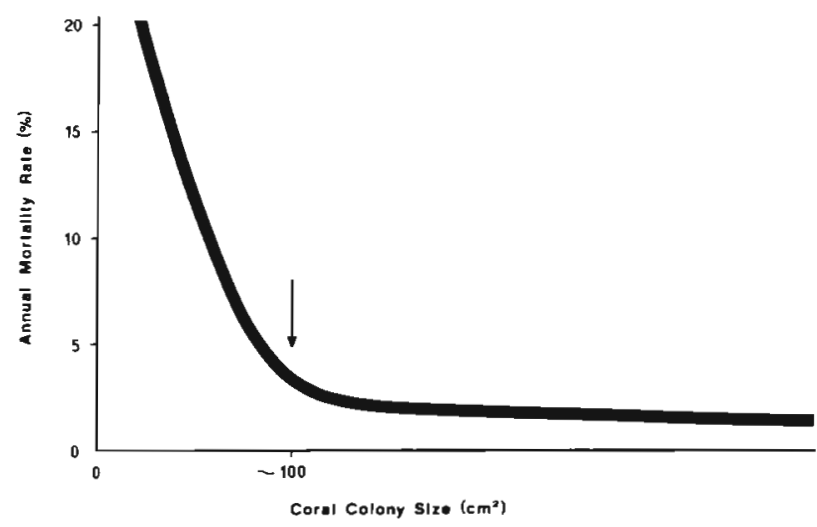

Fig. 1. Approximate annual mortality rate of corals as a function of colony size. Beyond the inflection point (arrow), there is little decrease in mortality rate with increasing coral colony size. Adapted from data of Connell (1973)

\footnotetext{
- Cook (1979), stressing the importance of vegetative reproduction in reducing the probability of mortality for plants, suggested that the extinction of the genotype becomes up to half as likely if two independent mortality events must occur' However, the probability of genotype extinction should be the product of the probabilities of mortality for all independent members of the genotype
}

ments may subsequently produce fragments also, i.e. a geometric increase in colony number is possible. Theoretically, it appears that clones of fragmenting species have the potential to be virtually immortal, barring a catastrophic event (Harper, 1977) affecting the entire reef area on which all members of the clone occur.

Over evolutionary time, organisms capable of both reproductive modes should achieve a balance between sexual and asexual reproduction (Williams, 1975). Parthenogenetic organisms, for example, due to the great short-term advantage of asexual reproduction typically produce several asexual generations per each sexual generation. Usually, the different offspring types have different ecological roles, asexual produced during stable, predictable periods and sexual in response to unfavorable or less predictable conditions (Williams, 1975). Similarly, corals adapted to reproduce extensively by fragmentation should put more energy into growth and less energy into sexual reproduction per unit tissue biomass than corals less dependent on fragmentation or non-fragmenters. Here, the role of fragments should be to gain local distribution, colonize substrata (e.g. sand, space occupied by competitors) that larvae cannot, acquire space from competitors, and to spread the risk of mortality over several individuals. Because of the frequency of disturbances " or altered conditions affecting large reef areas (Scatterday, 1974; Antonius, 1977), sexual reproduction should be most advantageous in these corals as a mechanism for long distance dispersal, i.e. dispersal to other reefs (Williams, 1975; Jackson, 1979).

In addition to dispersal, Williams (1975) suggested that the sexual production of genetically diverse offspring would increase the probability of successful colonization of new locations. Further, Glesener and Tilman (1978) argued that sexuality is maintained in a community of interacting organisms by increasing the uncertainty of the direction and intensity of selection imposed by their interactions, i.e. the sexual production of genetically diverse offspring is an adaptation to the unpredictability of the genotypes of sexually pro-

- Most coral reefs are located in areas of frequent storm activity (Ball et al., 1967; Stoddart, 1971). An average of 4.5 hurricanes and 3.4 tropical storms occur in the Caribbean each year (Glynn et al., 1965). Hurricanes strike Belize reefs every 10 yr on the average (Stoddart, 1963); Ball et al. (1967) estimate that any particular Florida reef is affected by hurricanes once every 6 yr In the Pacific, 70 cyclones of at least tropical storm strength $(34-63 \mathrm{kt}$ winds) passed within 180 nautical miles of Guam from 1948 to $1975\left(\bar{X}=2.5 y^{-1}\right)$ with significant typhoons (> $64 \mathrm{kt}$ winds) affecting Guam every 7 yr (Randall and Eldredge, 1977). Cyclones also occur frequently at New Caledonia and on the Great Barrier Reefs where 2 to 3 cyclones $\mathrm{yr}^{-1}$ affect some part of the Queensland coast (Brandon, 1973; Chevalier, 1973) 
duced competitors and predators. These considerations are beyond the scope of the present paper although the relatively limited investment in sexual reproduction by several major reef-building corals (table 8 ) would seem not to support these hypotheses.

Thus, reduced allocation of energy to sexual reproduction among fragmenting corals and the occurrence of fragmentation among corals with low mortality rates per colony will be considered evidence favoring the hypothesis that fragmentation has been selected for in those corals.

\section{EVIDENCE FOR REPRODUCTION BY FRAGMENTATION}

\section{Morphology and Habitats}

\section{Programmed Detachment}

Asexual reproduction is highly developed in Goniopora stokesi (Poritidae) (Rosen and Taylor, 1969) and in the Fungiidae (Wells, 1966), both of which have adopted a free-living lifestyle. Fungiids are initially connected to the substratum by a short stem but eventually become detached, presumably by dissolution of or very limited production of skeletal material at the intersection of the polyp and stem. The stem, which remains attached to the substratum, may survive and generate more polyps in this manner (Wells, 1966). In addition, the detached polyps may produce new polyps on either their oral or aboral surface, which also break away and live free on the substratum. This double mode of asexual reproduction results in clumps of adults (clones) that all originated from a single planula larva (Wells, 1966).

In Goniopora stokesi, 'polyp balls' consisting of 1 to 30 polyps and a spherical, unattached skeleton are formed on the surface of adult colonies (Rosen and Taylor, 1969). Many 'polyp balls' can be produced at a time and may comprise $25 \%$ of the surface area of the parent colony. When the 'polyp balls' reach a diameter of about $2 \mathrm{~cm}$, they drop off and lie free on the surrounding sand. Rosen and Taylor (1969) concluded that, similar to the fungiids, this mode of asexual reproduction is an adaptation for colonizing sandy substrates. This conclusion is supported by Sheppard's (1981) work in the Chagos Islands. He found that $G$. stokesi 'polyp balls' colonized sand along lagoon reef margins, eventually resulting in extension of reef slopes.

Except that asexual reproduction does not occur, the Caribbean coral Manicina areolata, bears a number of resemblances to the Indo-Pacific fungiids (Goreau and Goreau, 1960). Manicina areolata is initially attached to a hard substratum by a small, weak stem that is not enlarged as the coral grows. Eventually the colony breaks off and lives free on soft sediment areas around reefs. Both the fungiids and $M$. areolata tend to have rather flattened adult shapes with a large surface area relative to skeletal volume, can efficiently rid themselves of sediment, and can right themselves if overturned (Goreau and Goreau, 1960).

In all 3 of these examples, the corals are presumably released from the parent or stem when they have reached a size and shape likely to survive on a sandy substrate, an apparently suitable habitat for adults that cannot be colonized by larvae (Goreau and Goreau. 1960). Goniopora stokesi and the fungiids, due to asexual reproduction, are frequently found in extensive, monospecific clumps or patches (Wells, 1966; Rosen and Taylor, 1969; Sheppard, 1981). Also, the fungiids and Manicina areolata have determinate growth, so colonizing sand substrates may have the advantage of avoiding being overgrown or overtopped by reefdwelling corals with indeterminate growth.

\section{Caribbean Corals}

The dominant shallow-water ( $\leq 6 \mathrm{~m}$ depth) coral on many Caribbean reefs, including exposed fringing and barrier reefs, is the elkhorn coral Acropora palmata (Fig. 2a), which often occurs in dense stands (Goreau, 1959; Storr, 1964; Scatterday, 1974). It was recently proposed that detachment of branches during periodic disturbances may be the primary mode of reproduction and distribution for this species (Highsmith et al., 1980). In Belize, $46 \%$ of A. palmata branches and branch fragments broken off during Hurricane Greta, and which landed in sand-bottomed grooves, survived as did the original basal region of most colonies (Highsmith et al., 1980). Since there are typically several branches per colony*, and some branches broke into more than one piece, the total number of live elkhorn colonies on the reef apparently increased as a result of the storm. Survival of $A$. palmata fragments generated by storms has also been noted in Florida (Ball et al., 1967; Perkins and Enos, 1968) and Puerto Rico (Glynn et al., 1965); at Anegada, British Virgin Islands, many live colonies are detached from their original base (Dunne and Brown, 1979). At Jamaica, juvenile $A$. palmata are uncommon (Jackson, 1979) and at Curacao, only 2 of 252 juvenile corals in a series of 1 $\mathrm{m}^{2}$ quadrats placed between $3 \mathrm{~m}$ and $9 \mathrm{~m}$ depth were A. palmata (Bak and Engel, 1979). Based on the lack of

\footnotetext{
- An average of 13 branches per colony (range 5-32, N $=65$ colonies) occur on large Acropora palmata colonies in the San
} Blas Islands, Panama (unpubl. own obs.) 
juveniles and the frequent observation of new colonies developing from fragments, Bak and Engel (1979) also suggested that $A$. palmata depends heavily on asexual propagation.

In the San Blas Islands, Panama, I recorded the proportion of Acropora palmata colonies derived from fragments (Fig. 2b). These data (Table 3) indicate that about two-thirds of the colonies originate asexually, in agreement with Bak and Engel's (1979) observations. Since hurricanes seldom affect Bonaire, Curacao, or the San Blas region, some combination of mechanical instability due to branch length, bioerosion (Hernandez-Avila et al., 1977), and minor storms, may be responsible for coral breakage in these locations. The number of fragments in reef grooves and sediment troughs, upside down colonies, and detached colonies of large size, suggest wave action is an important

Table 3. Acropora palmata. Number of colonies originating from asexual reproduction at several sites in the San Blas Islands, Panama. Colonies were examined as encountered while swimming parallel transects in zones of abundant A. palmata cover

\begin{tabular}{|lcc|}
\hline Location & $\begin{array}{c}\text { Percent } \\
\text { asexual }\end{array}$ & $\begin{array}{c}\text { Total No } \\
\text { colonies }\end{array}$ \\
\hline Holandes Cays & 69 & 321 \\
Salada Salada & 73 & 348 \\
Marsagantupo & 68 & 472 \\
Midiatupo & 62 & 483 \\
Acuardargana & 76 & 446 \\
\hline \multicolumn{3}{l}{ Total } \\
Although Acropora palmata fragments have characteristic \\
shapes, it was sometimes impossible to determine the \\
origin of colonies. When there was doubt as to a colony's \\
origin, it was assigned to sexual reproduction. When it \\
was not possible to see the base, it was not counted. \\
Because of growth onto the substratum and production of \\
new branches, older fragments become increasingly \\
difficult to recognize
\end{tabular}

source of coral breakage on San Blas reefs. Small storms, called Chocosanos, do occur in this region.

In addition, I examined the staghorn coral Acropora cervicornis (Fig 2c) both in small clumps (Table 4) and at $1-\mathrm{m}$ intervals along transects in large patches (Table 5) and recorded whether the colonies were attached, detached, or reattached. Approximately $40 \%$ of the 2105 colonies were detached, $47 \%$ reattached, and only $10 \%$ to $16 \%$ attached in their original location. Many colonies in the attached and reattached categories have very weak stems that break off at the slightest touch. The stems are seldom covered by live tissue and are consequently extensively infiltrated and weakened by burrowing sponges. Detached colonies, especially within large patches, are relatively stable under normal conditions because their branches are interwoven with those of other colonies. Many of the clumps occur in depressions and appear to originate by the transport of colonies from other locations. Clumps isolated on sand were not included in the study (Table 4) because all colonies in such clumps are detached or reattached to each other and would have consequently biased the data. A. cervicornis is most abundant (moderately exposed forereefs) at depths of $3 \mathrm{~m}$ to $10 \mathrm{~m}$ in my San Blas study sites, but is often the dominant coral at depths of $15 \mathrm{~m}$ to $20 \mathrm{~m}$ at other Caribbean locations (Goreau, 1959; Tunnicliffe, 1978, 1980; Highsmith et al., 1980).

At Jamaica where much of the forereef between -5 and $-30 \mathrm{~m}$ is dominated by Acropora cervicornis, Tunnicliffe $(1978,1980)$ also found that over $80 \%$ of the live colonies had been broken off at the base which was usually not covered by live tissue and thus infested with boring sponges. In addition, one or more branches had been broken off in over $60 \%$ of the $A$. cervicornis colonies. The ubiquitous breakage and redistribution of fragments plus the almost complete absence of sexual recruits led Tunnicliffe $(1978,1980)$ to conclude that the great success of $A$. cervicornis was due to frequent fragmentation resulting in both repro-

Table 4. Acropora cervicornis. Mean number of colonies in small clumps that were attached, detached, or reattached to the reef substratum. Both locations are in the San Blas Islands, Panama. Number of clumps in parentheses

\begin{tabular}{|c|c|c|c|c|c|}
\hline \multirow[b]{2}{*}{ Location } & & \multirow[b]{2}{*}{ Per clump } & \multicolumn{2}{|c|}{ No. of colonies } & \multirow[b]{2}{*}{ Reattached } \\
\hline & & & Attached & Detached & \\
\hline \multirow[t]{3}{*}{ Salar (39) } & $\bar{x}$ & 17.2 & 1.7 & 7.6 & 7.9 \\
\hline & Range & $2-65$ & $0-8$ & $0-23$ & $0-40$ \\
\hline & Percent & & 10 & 44 & 46 \\
\hline \multirow{3}{*}{ Achutupo (31) } & $\bar{x}$ & 15.0 & 1.6 & 6.3 & 7.1 \\
\hline & Range & $5-49$ & $0-11$ & $0-18$ & $0-40$ \\
\hline & Percent & & 11 & 42 & 47 \\
\hline
\end{tabular}



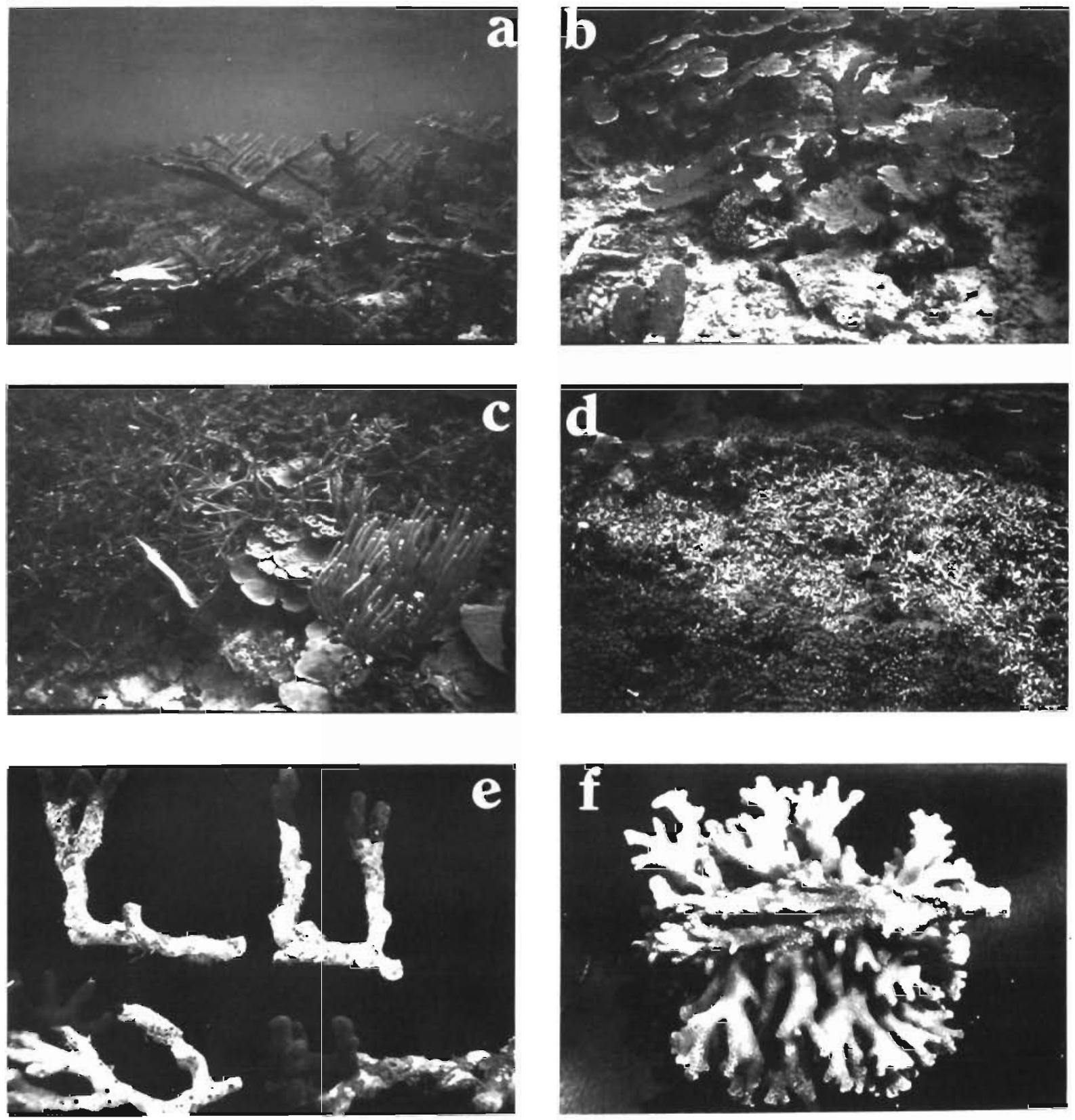

Fig. 2. (a) Acropora palmata at Bugatupo Reef, San Blas Islands, Panama. Note detached colony on left and branch stumps in center of picture. (b) A palmata fragments at edge of dense stand. (c) Edge of A. cervicornis patch at Achutupo Reef, San Blas Islands, Panama. (d) Porites furcata patch with hole (light area) in patch possibly due to waves. Bugatupo Reef, San Blas Islands, Panama. (e) Detached $P$. furcata colony showing change in growth direction indicating colonies were previously attached with upward axis of growth from right to left. (f) Underside of a detached Pocillopora damicornis colony showing change in growth direction (into plane of photo). The colony was originally attached on the right end

duction and acquisition of space and that the fragile growth form (slender branches with high growth rate) of this coral has evolved to facilitate breakage.

Similarly, the majority of Acropora cervicornis colonies within the Florida Reef Tract apparently develop from broken branches of other colonies rather than from larval settlement (Gilmore and Hall, 1976). In fact, the rapid recovery of Florida reefs from hurricane damage has been attributed to the survival and growth of numerous $A$. cervicornis fragments dispersed by the storms which increased the number of sites of active reef growth (Shinn, 1976; see also Perkins and Enos, 1968). Interestingly, no $A$. cervicornis larvae settled during an 8-month study of coral recruitment at Carysfort Reef, Florida (Dustan, 1977). A. cervicornis sexual recruitment was also quite rare at Jamaica during a 10- 
mo study (Sammarco, 1980; see also Tunnicliffe, 1980). During a 1-year study of the distribution and abundance of juvenile corals at Curacao and a 1-month study at Bonaire, no juveniles of $A$. cervicornis were found although adults were present at the study sites and on other reefs in the region (Bak and Engel, 1979; Bak, pers. comm.). Also at Curacao and Bonaire, the delicately branched Madracis mirabilis appears to reproduce and spread primarily by breakage and survival of branches even though it usually occurs in more protected locations than the acroporans (Bak, 1976; Bak and Engel, 1979).

Another rather delicate branching coral in the Caribbean is Porites furcata which forms extensive patches at depths of 3 to $10 \mathrm{~m}$ on San Blas reefs (Fig. 2d). To evaluate the relationship of colony position within the patch to attachment to the substratum, three $25-\mathrm{m}$ transects were placed over reef areas dominated by $P$. furcata at each of 3 islands ( 9 transects total). At each meter, colonies every $10 \mathrm{~cm}$ on either side of the transect out to $1 \mathrm{~m}$ (21 obs. per transect $\mathrm{m}$ ) were examined to see if they were attached, detached, loose, or dead and their position in the patch, i.e. clump, edge, or hole, recorded. The occurrence of attached, detached, and loose colonies of live $P$. furcata is significantly affected by patch position (Table 6 ; $\mathrm{P} \ll 0.001, \mathrm{X}^{2}>400$ at each location, d.f. $=4$ ). Colonies in the dead category were not included in the analysis because those in holes (Fig. 2d) were not actually in situ but were broken branches and stems apparently revealed by removal of overlying live colonies, presumably by wave action. Since only about $20 \%$ of live $P$. furcata colonies are attached to the substratum, and then only weakly so due to the general occurrence of boring sponges in their stems (live tissue extends only a few $\mathrm{cm}$ below branch tips), it is not surprising that holes in the patches are common. These holes are recolonized by detached heads which are in all cases significantly more abundant at the edge of patches and in holes than expected by $\mathrm{X}^{2}$ (Table 6). Examination of detached colonies usually reveals a $90^{\circ}$ shift in the major growth axis (Fig. 2e), indicating that the colonies originated in patches and toppled into holes. The redistribution of branching Porites colonies has also been reported at other Caribbean locations (Kissling, 1965; Connell, 1973; Glynn, 1973; Highsmith et al., 1980).

The predominant massive coral on most Caribbean reefs is Montastrea annularis which is broadly distributed with respect to both exposure and water depth (e.g. Goreau, 1959; Mesolella, 1967; Glynn, 1973; Milliman, 1973). Asexual reproduction can occur in 3 growth forms of this species: plates, columns, and hollow domes. Thin, overhanging skeletal plates, which are often produced around the edges of large colonies (Smith and Tyler, 1975; Jones, 1977), occasionally break off and colonize the adjacent substratum, resulting in lateral patch reef extension (Jones, 1977; Jones applied the term, calving; in the sense that icebergs calve from glaciers, to fragmentation of colonies). Columnar growth forms are produced when the surface of a single, hemispheroidal colony becomes divided into several sections (Fig. 3d), eventually resulting in the upward growth of a number of columns, some of which may become detached due to bioerosion or storms (Lewis, 1960; Barnes, 1973; Scatterday, 1974, 1977; Jones, 1977). The large, domeshaped colonies of $M$. annularis (Marszalek et al., 1977), hollowed out in large part by bioeroders (Storr, 1964), eventually collapse, breaking into several independent colonies (Smith and Tyler, 1975).

\section{Eastern Pacific}

The dominant reef-building coral in the tropical eastern Pacific is Pocillopora damicornis, a fast-growing coral with numerous branches (Glynn et al., 1972; Porter, 1972; Glynn and Macintyre, 1977; Glynn et al., 1979). Most $P$, damicornis reefs occur on the sheltered side of offshore islands but occasionally occur at more exposed sites (Glynn et al., 1972; Glynn and Macintyre, 1977). Along the edges of $P$. damicornis reefs,

Table 5. Acropora cervicornis. Number of attached, detached, or reattached colonies along and at $50 \mathrm{~cm}$ and $100 \mathrm{~cm}$ to either side ( 5 obs. at each $\mathrm{m}$ ) of transects through large patches. See Table 4 for definitions of categories. All locations are in the San Blas Islands, Panama

\begin{tabular}{lcccr|}
\hline Location & Transect length $(\mathrm{m})$ & No. attached & No. detached & No. reattached \\
\hline Salar & 35 & 42 & 57 & 93 \\
Achutupo & 39 & 42 & 56 & 107 \\
Ucubsui & 56 & 32 & 99 & 163 \\
Acuardargana & 53 & 44 & 135 & 101 \\
\hline Total & 183 & 160 & 347 & 464 \\
Percent & & $16 \%$ & $36 \%$ & $48 \%$ \\
\hline
\end{tabular}


Table 6. Porites furcata. Substrate attachment relative to position within or adjacent to dense patches of the coral. Clump: colony located within the patch surrounded by other P. furcala; edge: edge of patch; hole: hole within or adjacent to the patch (see Fig. 2d); other: corals of other species or coral debris; attached: connected to substratum; detached: not connected to substratum; loose: stem broken but supported in growth position by neighboring colonies. Values expected by $X^{2}$ test are shown in parentheses

\begin{tabular}{lcccc|}
\hline Location & Transect length $(\mathrm{m})$ & No. attached & No. detached & No. reattached \\
\hline Salar & 35 & 42 & 57 & 93 \\
Achutupo & 39 & 42 & 56 & 107 \\
Ucubsui & 56 & 32 & 99 & 163 \\
Acuardargana & 53 & 44 & 135 & 101 \\
\hline Total & 183 & 160 & 347 & 464 \\
Percent & & $16 \%$ & $36 \%$ \\
\end{tabular}

clusters of branches commonly break free due to waves, bioerosion, or excavation by foraging fish and colonize the adjacent rubble/sand reef slope, resulting in lateral growth of the reef (Porter, 1972; Glynn, 1974, 1976, in press; Wellington, 1981). Transect data for 3 reefs in the Gulf of Chiriqui, Panama, clearly show that $P$. damicornis heads on the reef slope below the reef edge (Fig. 3a) are unattached and that a third or more of heads along the reef edge and in the reef itself are loose, i.e. clumps of branches detached from their stem but held in growth position by neighboring colonies (Fig. 4). These data combined with obvious changes in growth orientation of the detached clumps (Fig. 2f) strongly indicate that they originated from the reef. It should be noted, however, that $P$. damicornis fragments on reef slopes in the Gulf of Chiriqui probably have a higher mortality rate than colonies in the reef proper because the predatory seastar Acanthaster planci feeds preferentially on corals on the reef slope (P. W. Glynn, pers. comm.). A. planci does not occur on reefs in the Gulf of Panama.

Preliminary results from a recruitment experiment give an indication of the rate at which Pocillopora damicornis fragments colonize the reef slope. At Isla Uva, 5 study plots, each $30 \mathrm{~m}^{2}$, along the reef edge were cleared of all living corals, including $173 P$. damicornis. After $4.5 \mathrm{mo}$, a total of $25 \mathrm{P}$. damicornis colonies with a mean circumference of $42 \mathrm{~cm}$ (sd = $15 \mathrm{~cm}$ ) had recruited and after 8 mo there were 38 live colonies (mean circ. $=38 \mathrm{~cm}, \mathrm{sd}=16 \mathrm{~cm}$ ) present in the plots. Five colonies from the previous census were dead or missing. After twelve months, 66 colonies (mean circ $=38 \mathrm{~cm}$, sd $=12 \mathrm{~cm}$ ) were found in the plots. Only 18 of these heads were present at the 8 -mo point. A storm that occurred between the last two censuses resulted in the breakage and movement of many corals at Uva (A. Velarde, pers. comm.), probably accounting for this high turnover rate. The size of the new colonies clearly indicates they were fragments. If recruitment continues at this rate $\left(Y=5.35 \mathrm{x}-0.5, r^{2}\right.$
$=0.98$; where $Y=$ number of colonies; $\mathrm{x}=$ number of months), the original number of colonies will be restored in the study areas in less than 3 yr.

The dome-shaped colonies of another eastern Pacific coral, Pavona clavus, like the Montastrea colonies mentioned above, are weakened by burrowing organisms, especially Lithophaga spp. (Table 7), resulting in collapse and breakage of the domes into several colonies (unpubl. obs.).

\section{Indo-West Pacific}

In Guam, most colonies of the staghorn coral Acropora aspera are derived from fragments, $79 \%$ of colonies living unattached and the remainder, though attached, apparently originating from fragments (Birkeland et al., 1979; see also Randall and Eldredge, 1977). Fragmentation, combined with regeneration and fast growth rates, account for the dominance of $A$. aspera and $A$. acuminata in the Inner Reef Flat Subzone (350 to $380 \mathrm{~m}$ wide) at Guam (Randall, 1973a). Reports of Acropora spp. fragments founding new colonies also come from Australia (Stephenson et al., 1958; Connell, 1973), Enewetak (Stimson, 1978), Chagos (Sheppard, 1981) and the Red Sea (Mergner, 1971). In the latter case, Acropora fragments from the upper reef slope gave rise to an entire reef zone (Secondary Acropora Zone) on the lower slope.

Among the Poritidae, Porites compressa - probably the most important reef-building coral in Hawaii (Maragos, 1972; Dollar, 1975; Stimson, 1978) - forms thickets which expand by growth of individual colonies and by survival and growth of broken branches around the periphery of the thicket. Thickets may also be initiated in new locations by the survival of branches dislodged and scattered about by waves (Maragos, 1972; Dollar, 1975). Other branching poritids may reproduce in this manner also (Connell, 

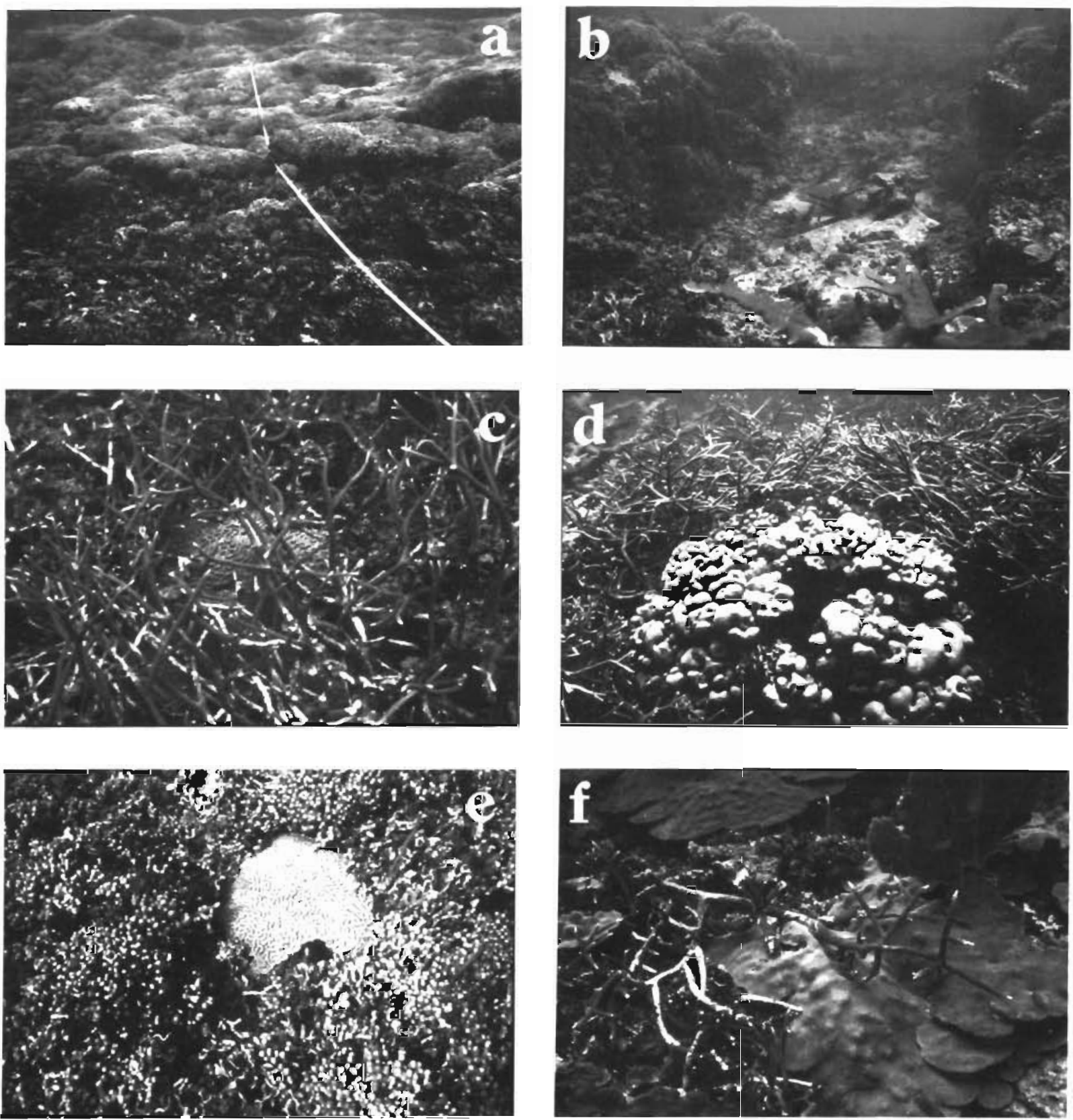

Fig. 3. (a) Transect site on Pocillopora damicornis reef, Isla Uva, Gulł of Chiriqui. Note detached corals below reef edge. foreground; see Fig. 4. (b) Groove between 2 coral spurs, Salar Reef, San Blas Islands, Panama. Note Acropora palmata fragments in groove; far end is dammed. (c) Massive head of Diploria being overtopped by the staghorn coral $A$ cervicornis. (d) Massive head of Montastrea annularis being overtopped by $A$. cervicornis. Branches of the latter species grow approximately $10-15 \mathrm{~cm}$ $\mathrm{yr}^{-1}$. (e) Massive colony of Diploria in process of being overtopped by Porites furcata. (f) Massive head of M. annularis on which a fragment of $A$. cervicornis has fallen. The latter has been killed at places where the 2 corals are in contact but the massive coral is in danger of being shaded out by future growth of the live parts of the staghorn coral

1973; Randall and Eldredge, 1977). At many IndoPacific locations, the massive coral Porites lutea forms microatolls on intertidal reef flats (Dana, 1853; Scoffin and Stoddart, 1978; Highsmith, 1980a, 1981). Low tides prevent upward growth of microatolls so live tissue is restricted to the periphery of the colonies resulting in a flat, more or less circular shape. At Enewetak, microatolls detached from the reef due to their relatively small basal attachment and the activity of boring organisms, are transported by currents across the smooth reef flat to the edge of the Iagoon where their growth is less restricted by low tides (Highsmith, 
Fig. 4. Pocillopora damicornis. Percentage of transects at 3 reefs in the Gulf of Chiriqui, Panama (Isla Uva, 10 transects; Isla Secas, 10 transects; unnamed island, 7 transects). Observations were made on 5 colonies at each m mark on the transect, 1 under the transect line and 2 on either side of the line at distances of $50 \mathrm{~cm}$ and $100 \mathrm{~cm}$. The transect was placed with the reef edge near the center Total no. of observations $=1350$ attached, detached, and loose heads along $9-\mathrm{m}$

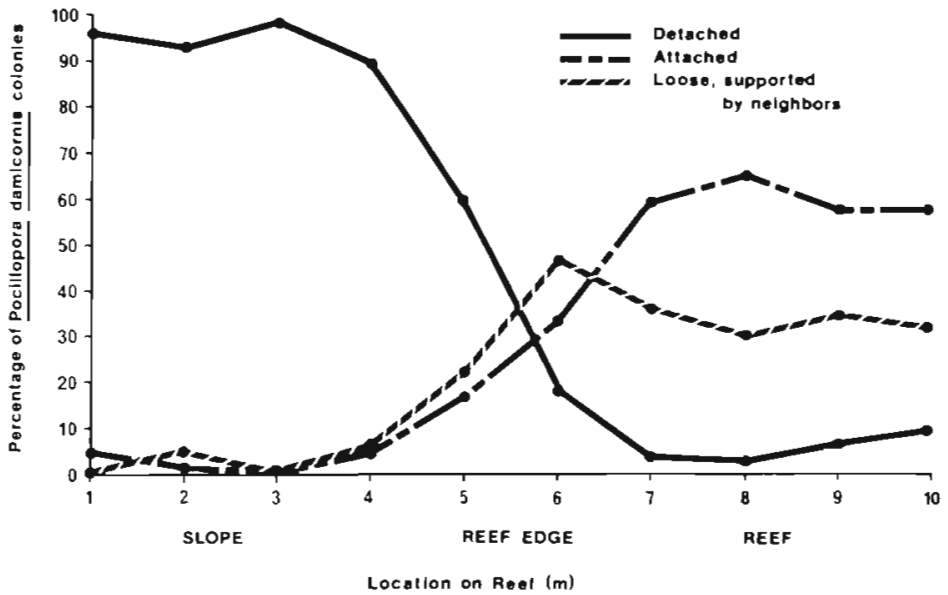

1980a). Frequently, parts of the microatoll margin which have encrusted onto the reef flat, break off the colony when it is dislodged and remain attached to the reef at the original site. Up to a dozen separate colonies, marking the outline of the original colony, may result from the detachment of a single microatoll (Highsmith, 1980a). For the closely related P. lobata in Hawaii, Dollar (1975) reported fragments were broken from colonies during a winter storm and transported several meters down the reef slope. The overall movement of living coral fragments and detached colonies resulted in a shift of peak percentage live cover 10-15 $\mathrm{m}$ further offshore and 5-10 $\mathrm{m}$ deeper.

\section{Division of Colonies by Partial Mortality}

Another mechanism of separation of single colonies into several partially independent units involves death of the intervening tissue between various portions of the colony growth surface (Lewis, 1960, 1974; Barnes, 1973; Connell, 1973; Scatterday, 1974, 1977). Thus, the

Table 7. Mean number of Lithophaga spp. (primarily L. aristata and L. plumula) burrows per $100 \mathrm{~cm}^{2}$ in the underside of Pavona clavus hollow domes. Live: burrows still occupied by the bivalve. Dead: burrows broken open, probably by the triggerfish Pseudobalistes naufragium, and bivalves removed. Parentheses: no. of quadrats

\begin{tabular}{|c|c|c|c|}
\hline \multirow[b]{2}{*}{ Head } & \multicolumn{3}{|c|}{ Mean no. Lithophaga spp. $1100 \mathrm{~cm}^{2}$} \\
\hline & Live & Dead & Total \\
\hline A (5) & 16.2 & 7.8 & 24.0 \\
\hline B (6) & 5.2 & 16.7 & 21.9 \\
\hline C (4) & 7.5 & 14.8 & 22.3 \\
\hline$D(4)$ & 11.8 & 13.0 & 24.8 \\
\hline$E$ (4) & 6.5 & 23.3 & 29.8 \\
\hline$F \quad(2)$ & 11.5 & 5.0 & 16.5 \\
\hline
\end{tabular}

coral tissue is divided into several sections but the skeleton is not fractured, at least initially (skeletal surfaces not covered by live tissue are likely to be invaded by boring organisms, increasing the probability of skeletal fracture; Tunnicliffe, 1978; 1980; Highsmith, 1981). This type of colony separation occurs in the Caribbean corals Montastrea annularis (Lewis, 1960, 1974; Scatterday, 1974, 1977; Hughes and Jackson, 1980; see Fig. 3d), Porites astreoides (Lewis, 1974; Bak, 1976), Agaricia agaricites (Lewis, 1974; Bak, 1976; Hughes and Jackson, 1980), A. lamarcki (Hughes and Jackson, 1980), Helioseris cucullata (Hughes and Jackson, 1980), and Meandrina meandrites (Bak, 1976) and in the eastern Pacific coral Pavona clavus (Glynn et al., 1972; their Fig. 7). In a $90 \mathrm{~m}^{2}$ study area on the reef slope at Heron Island, Australia, one or possibly 2 colonies of each of 2 species of Montipora had separated into over 100 colonies and, similarly, 1 or 2 Acropora formosa had split into 77 colonies and 1 or 2 A. hyacinthus into 45 colonies (Grassle, 1973; see also Sheppard, 1980a). Branching Porites colonies also separate in this manner at Heron Island (Connell, 1973).

This type of colony separation may not result in as complete independence of mortality for the resultant individuals as fragmentation, depending upon the major sources of mortality, and does not provide the opportunity for increased local distribution and acquisition of space although skeletal weak points resulting from these dead zones may contribute to eventual fragmentation.

\section{Summary}

Morphologies of fragmenting species essentially span the entire range of coral growth forms from small, delicately branched to large, massive colonies. While some of these corals occur in protected habitats, nearly 
all of them also occur in exposed sites and some are even confined to or at least are most abundant on forereefs. Certainly, all occur at locations affected by storms. Thus, the variety of growth forms, type of habitats occupied and geographical range of the corals discussed above are in contrast to those expected if fragmentation were generally maladaptive.

\section{Life History Characteristics}

Data on life history features are limited to just a few of the several hundred hermatypic coral species but the available evidence (Table 8) generally supports the theoretical predictions made earlier. Non-fragmenting coral species tend to (1) release planulae throughout most of the year, (2) release more planulae per colony than corals of a similar size in the fragmenting group, (3) become sexually mature at an early age ( $\approx 2$ yr $)$, (4) have many juveniles present on reefs, (5) grow slowly or at least more slowly as they become older, (6) have determinate growth resulting in relatively small adult colony sizes, (7) have a relatively short life expectancy, and (8) are poor space competitors (Maragos, 1972; Connell, 1976; Bak and Engel, 1979).

Life history characteristics associated with fragmenting species (Table 8) are generally the opposite of those for non-fragmenting corals. Fragmenting species (1) may release gametes rather than brood larvae, or else (2) produce fewer larvae per colony, (3) may only be ripe for a few months each year, (4) may not become sexually mature until 8-10 years old, (5) populations are dominated by adults with juvenile colonies being rare, (6) have high growth rates, (7) have indeterminate growth and become quite large, (8) are long-lived, and (9) are, except for Porites lutea, moderate to very good space competitors (Maragos, 1972; Connell, 1976; Shinn, 1976; Bak and Engel, 1979; Sheppard, 1979).

The Fungiidae, to the extent generalizations can be made from data on only a few members of this family, have characteristics of both groups. Release of planula larvae has actually only been observed in one species but in that case several hundred were released daily for several days each month for 8 mo of the year (Wells, 1966). Conversely, no larvae were found during a ninemonth study of Fungia scutaria at Hawaii, although young heads, produced by budding, were common (Harrigan, 1972). I have listed this family as having small adult sizes but some species become rather large, one reaching up to $1 \mathrm{~m}$ in length (Wells, 1966). It would be interesting to know whether or not various fungiids emphasize one or the other mode of reproduction and, if so, the life history characteristics associated with each.

In a study of 7 Hawaiian and 12 Enewetak coral species, Stimson (1978) only observed release of larvae in corals ( 2 Hawaiian and 7 Enewetak species) characteristically found on reef flats or in shallow water He suggested that reef flat or shallow water species were 'weedy' as indicated by production of numerous larvae, beginning at a comparatively early age $(\approx 2 \mathrm{yr})$, during all or most of the year. In contrast, 5 Hawaiian coral species characteristic of deeper water or with broad depth distribution, which did not release larvae, were examined histologically each month and eggs were found in 4 of the species but only 1 contained eggs more than 2-3 mo of the year. Stimson (1978) also found two shallow-water acroporans that did not release planulae and suggested they may reproduce by survival of branches broken off during storms. It has since been reported that one of them, A. aspera, reproduces almost entirely by fragmentation in Guam (Birkeland et al., 1979).

In addition to Stimson's (1978) observations, Duerden (1902) reported that Acropora and Montastrea (= Orbicella) species in Jamaica as a rule did not contain sexual cells and Marshall and Stephenson (1933) only observed release of planulae in two of ten Great Barrier Reef corals.

Possibly corals reproducing by fragmentation, rather than brood larvae, limit their expenditure on sexual reproduction to the release of sperm and eggs during a relatively short period of the year and perhaps not even annually (Connell, 1973). In this respect, fragmenting coral species resemble a number of fresh-water invertebrates that typically reproduce asexually as long as conditions are favorable and sexually only in anticipation of unfavorable conditions, such as winter. However, sexual phases may be infrequent or even absent in large lakes (Williams, 1975; Maynard Smith, 1978) where, similarly to tropical marine habitats, environmental conditions are relatively stable.

With regard to Stimson's (1978) finding that reef flat species tend to reproduce sexually, perhaps coral fragments are too unstable to colonize effectively certain habitats such as surf zones or wave-swept reef flats. Very steep or vertical walls may be another reef location neither readily colonized by fragments nor dominated by a fragmenting species and thus occupied by species emphasizing sexual reproduction or by a highly diverse assemblage of species reflecting chance larval settlement. Severely disturbed areas, i.e. where fragments have been killed or transported elsewhere, on reefs are also likely to be colonized initially by competitively subordinate species producing large numbers of sexual propagules (Mayor, 1918; Grigg and Maragos, 1974; Stoddart, 1974; Connell, 1978; Bak and Luckhurst, 1980).

There are many ecological explanations for the evolution of high growth rates in corals, e.g. escaping 
Table 8. Comparison of life history characteristics for corals whose abundance and distribution on reefs is due primarily to sexual reproduction or primarily to asexual reproduction. Dash: no information available

\begin{tabular}{|c|c|c|c|c|c|c|}
\hline Characteristics, Species & $\begin{array}{l}\text { Release } \\
\text { larvae }\end{array}$ & $\begin{array}{l}\text { Juveniles } \\
\text { abundant }\end{array}$ & $\begin{array}{l}\text { Growth } \\
\text { rate }^{b}\end{array}$ & $\begin{array}{l}\text { Adult } \\
\text { size }\end{array}$ & $\begin{array}{c}\text { Life } \\
\text { expectancyc }\end{array}$ & Sources $^{\mathrm{d}}$ \\
\hline \multicolumn{7}{|c|}{ Sexual reproduction dominant } \\
\hline Agaricia agaricites & Yes & Yes & - & small & short & $1,2,3$ \\
\hline Cyphastrea ocellina & Yes & $\longrightarrow$ & low & small & short & $4,5,6,7,8$ \\
\hline Pocillopora damicornis ${ }^{\mathrm{e}}$ & Yes & Yes & low & small & short & $5,6,7,8$ \\
\hline Stylophora pistillata & Yes & Yes & low & small & short & 9 \\
\hline \multicolumn{7}{|c|}{ Asexual reproduction dominant } \\
\hline Acropora aspera & No & No & high & - & - & 8,10 \\
\hline Acropora cervicornis & No & No & high & large & long & $11,12,13,14,15,16,17$ \\
\hline Acropora palmata & No & No & high & large & long & $3,11,14,16,18,19$ \\
\hline Porites compressa & No & - & high & large & long & $5,6,7,8$ \\
\hline Porites lutea ${ }^{e}$ & No & No & high & large & long & $20,21,22$ \\
\hline Pocillopora damicornis ${ }^{e}$ & No & No & high & large & long & $23,24,25,26,32$ \\
\hline Madracis mirabilis & - & No & high & large & - & $2,27,28$ \\
\hline Montastrea annularis & No & No & high & large & long & $2,3,11,14,29,30$ \\
\hline Fungiidae & see text & - & $\mathrm{f}$ & small & - & $5,6,31$ \\
\hline
\end{tabular}

(a) Observed to release larvae. Some corals not observed to brood larvae will, with further study, probably be found to do so

(b) Linear rate of branch extension or radial growth in massive corals. Low and high are relative to other species occuring in the same region and having a similar growth form. Rates are for long-term growth so species with high initial growth rates that soon decline (determinate growth) are considered to have a low growth rate

(c) For adult colonies

(d) 1: Dustan (1977); 2: Bak and Engel (1979); 3: Bak and Luckhurst (1980); 4: Edmondson (1929); 5: Harrigan (1972); 6: Maragos (1972); 7: Stimson (1976); 8: Stimson (1978); 9: Fishelson (1973); Loya (1976 b, c); Rinkevich and Loya (1979 a, b); 10: Birkeland et al. (1979); 11: Duerden (1902); 12: Gilmore and Hall (1976); 13: Shinn (1976); 14: Gladfelter et al. (1978); 15: Tunnicliffe (1978, 1980); 16: Sammarco (1980); 17: R. Bak (pers. comm.); 18: Jackson (1979); 19: Highsmith et al. (1980); 20: Highsmith (1979); 21: Highsmith (1981); 22: J. Stimson (pers. comm.); 23: Birkeland (1977); 24: Glynn (1977); 25: Glynn and Macintyre (1977); 26: Glynn (in press); 27: Bak (1976); 28: Bonem and Stanley (1977); 29: Smith and Tyler (1975); 30: Jones (1977); 31: Wells (1966); 32: Wellington (1981)

(e) Pocillopora damicornis has remarkably different life-history features in Hawaii and Panama (ref's in Table). In Panama, it is the major reef builder, is the competitive dominant, has a high growth rate $(\approx 3-4 \mathrm{~cm}-\mathrm{yr}$; Glynn, 1977), has indeterminate growth, and recruitment of sexual propagules is rare (Wellington, 1981; Glynn, in press). In Hawaii, P. damicornis is apparently a fugitive species, is competitively subordinate, has a low growth rate $(\approx 1.4 \mathrm{~cm}-y \mathrm{r}$; Edmondson, 1929) and small adult size, and is noted for production of planula larvae. These populations are probably genetically isolated but the origin of P. damicornis in the Eastern Pacific is controversial. It occurs in Miocene and Pliocene Fossi] deposits (Durham, 1966) but Panamanian $P$. damicornis reefs are only $\approx 6000$ yr old (Glynn and Macintyre, 19771 Glynn, in press). For a discussion of longdistance dispersal versus vicariance with regard to eastern Pacific corals, see Heck and McCoy (1978). Stimson (1978) noted $P$. meandrina reproduces very differently at Enewetak and Hawaii. Also, Porites haddoni $(=P$. lutea?) at Low Isles, Australia released large numbers of planulae from January through June (Marshall and Stephenson, 1933) but planulation has not been observed in P. lutea at Enewetak (J. S. Stimson, pers. comm.)

(f) Growth rates of Fungiidae are reported to be high by some workers (e.g. Ma, 1957) and low by others (e.g. Maragos, 1972). The latter found that growth in Fungia scutaria slowed with increasing size

the high mortality rates for small colonies or growing fast enough to shade-out competitors (Connell, 1973). High growth rates often result in large colonies which are the most susceptible to breakage due to mechanical instability, large surface area presented to currents, or weight. Thus, fragmentation may have originated as an inevitable consequence of selection for high growth rates. Whether corals have subsequently evolved any specific adaptations such as particular growth forms or skeletal features resulting in fragments of a size or shape most likely to survive as, for example, in the Fungiidae or Goniopora stokesi, is in need of investigation.
The relationship between the size and possible number of fragments produced by a colony is indicated in Fig. 5. It appears that most fragmenting species are near the large-fragment end of the continuum. The low survivorship of small fragments during storms (Highsmith et al., 1980) and high mortality rates for small colonies (Connell, 1973; Loya, 1976b, c; Schuhmacher, 1977; Hughes and Jackson, 1980) probably make asexual reproduction via numerous small fragments a less likely course of coral evolution. Some point must be reached toward the left end of the continuum (Fig. 5) where a coral is more successful by investing energy in production of large numbers of sexual propagules 


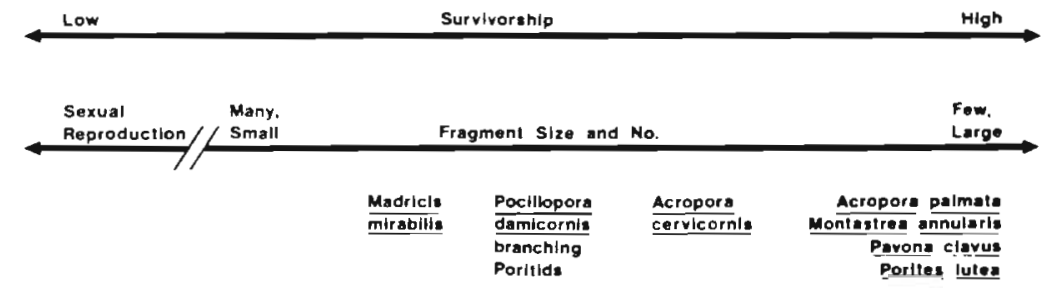

Fig. 5. Proposed relationship between coral fragment size and survivorship. A few examples are given, ranked according to typical fragment size. See text

rather than in growth of comparatively few fragments. The corals with relatively small fragments tend to occur in somewhat more protected habitats than those corals on the right end of the continuum. For a given level of survivorship, fragments should be larger in habitats where the sediment is less stable, i.e. where water energy is high, than in habitats where the sediment is more stable and, in both cases, fragments lacking efficient cleansing and righting behaviors should be larger than the fragments produced by corals with programmed detachment.

Fragment shapes most conducive to survival would seem to be those well developed in 3 dimensions, e.g. Acropora cervicornis in which branches tend to produce 2 or 3 new branches at 1-yr growth intervals ( $\approx$ $12 \mathrm{~cm}$ ) (Shinn, 1976; Tunnicliffe, 1978, 1980), so that regardless of how they come to rest, some part of the fragment will be off the substratum and, hence, less likely to be buried or scoured. Tunnicliffe $(1978,1980)$ found that $A$. cervicornis fragments with multiple branches were more likely to survive than unbranched fragments. Both $A$. cervicornis and A. palmata have dense, heavy skeletons (Highsmith, 1981) which may prevent multiple breakage of fragments into very small fragments and also reduce transport of the fragments, because of their weight, to less favorable reef zones (Tunnicliffe, 1978, 1980; Highsmith et al., 1980). Clearly, the potential for fragmenting is much greater in branching corals because branches grow rapidly, are produced in large numbers, and are readily broken by biological and physical disturbances. It has even been suggested that some species grow continuously and that branches not otherwise detached ultimately break of their own weight (Maragos, 1972; Bak, 1976).

With respect to Williams' predictions (Table 2), the characteristics of coral asexual offspring meet them rather well. Fragments are large relative to coral larvae or juveniles and production is continuous in that fragments are produced by colony growth, although actual fracture of the colony may be periodic. Fragments, by virtue of their large size, tend to remain near the parent where the environment is more predictable and the mortality rate is consequently lower. The fragments represent an instantaneous adult although how soon fragments actually reproduce sexually may depend upon their size and extent of breakage-related damage.
The characteristics of sexual offspring of corals, with the exception of dormancy (larvae may, however, delay settlement in the absence of appropriate cues; Harrigan, 1972; Rinkevich and Loya, 1979a), generally meet Williams' (1975) predictions also. Larvae, as well as juveniles, are small and are produced seasonally or periodically in at least some cases (Duerden, 1902; Wells, 1966; Loya, 1976; Stimson, 1978). Larvae may be planktonic for as little as $2 \mathrm{~d}$ or as long as several wk and presumably are widely dispersed relative to fragments (Harrigan, 1972; Connell, 1973; Rinkevich and Loya, 1979a). Larval mortality rates are unknown but are probably very high (Connell, 1973; Loya, 1976b, c). Coral reefs are relatively small, isolated structures in the oceans with the majority of their surface area composed of sand or other soft sediments (Cloud, 1959; Goreau, 1959; Storr, 1964; Mergner and Scheer, 1974; Purdy, 1974; James et al., 1976; Orme, 1977; Highsmith et al., 1980) which are unsuitable for larval settlement (Marion, 1883; Vaughn, 1909; Stephenson, 1931; Hada, 1932; Motoda, 1939), and having a large proportion of the hard substratum already occupied, particularly by potential predators and space competitors (e.g. corals, soft corals, gorgonians, sea anemones, hydroids, algae) (Harrigan, 1972; Schuhmacher, 1974; Benayahu and Loya, 1977; Birkeland, 1977; Jones, 1977; Birkeland et al., 1979; Rinkevich and Loya, 1979b; Highsmith, 1980b). Also, Storr (1964) reported the periodic occurrence of heavy siltation sufficient to smother small, juvenile corals. Thus, settlement sites are not only isolated and far apart but many of the otherwise most favorable sites on reefs are unstable, unavailable, or unsafe.

Mortality rates for juvenile coral colonies, like those for larvae, are not well documented but appear to be very high also (Connell, 1973; Loya, 1976b, c; Schuhmacher, 1977; Bak und Engel, 1979). For example, Harrigan (1972) found that when Pocillopora damicornis larvae settled on pieces of dead, algalcoated coral, the new juveniles were killed during the night by small crustacean and annelid predators. Similarly, Maragos (1972) found only 2 of 60 newly settled $P$. damicornis alive after a period of just 2 mo. Bak and Engel (1979) monitored 390 juvenile corals of various species for a period of 6 mo during which one-third died and one-third was damaged or prevented from growing by competitors or sedimentation. These may 
also be the major sources of mortality for small corals in Jamaica (Hughes and Jackson, 1980). During 2 consecutive 3.4 yr study periods, Connell (1973) found a clear relationship between colony size and mortality. For corals with surface areas of 1 to $40 \mathrm{~cm}^{2}, 41$ to $80 \mathrm{~cm}^{2}$, and $\geq 81 \mathrm{~cm}^{2}$, the percentage mortality per period was approximately $50 \%, 28 \%$, and $9 \%$, respectively. Thus, coral mortality rates appear to be strongly size dependent.

\section{Conclusions}

In view of the evidence presented above on the morphologies, habitats, and life histories of fragmenting corals, I conclude that reproduction by fragmentation occurs on a number of levels ranging from a rare or occasional event to a central feature in a coral's life, and that corals reproducing extensively by colony fragmentation have all the characteristics expected to have evolved in organisms that reproduce both sexually and by more traditional forms of asexual reproduction such as budding, runners, or parthenogenesis, i.e. several major reef-building corals have incorporated fragmentation into their life histories.

\section{ECOLOGICAL AND GEOMORPHOLOGICAL CONSEQUENCES}

Detached coral fragments usually move downslope or downstream (Mergner, 1971; Jones, 1977; Highsmith, 1980a). Acropora palmata and Porites lutea provide good examples. At Enewetak, P. lutea microatolls on reef flats are prevented from growing upward more than a few $\mathrm{cm}$ by emersion at low tide. Detached microatolls are moved downstream to the edge of the lagoon where the water is deeper, permitting additional growth and resulting in lagoonward extension of the reef. The pieces of microatoll remaining encrusted to the reef grow into new microatolls (Highsmith, 1980a). At Belize, A. palmata occurs in the shallow spur and groove zone of the reef where continued growth may be limited by the proximity of branch tips to the water surface or crowding. Branches broken off during storms fall into the sand-bottomed grooves where about one half survive. These branches initiate new colonies and the original colony regenerates branches (Highsmith et al., 1980).

On many reefs in the San Blas Islands, fragments of Acropora palmata, A. cervicornis, and Porites furcata have colonized the grooves in the spur and groove zone so successfully as to fill or dam them (Fig. 3b).

In the above examples, fragments colonize sand bottoms, an extensive habitat on reefs that cannot be colonized by larvae. Other corals reported to colonize soft bottoms in this manner are Acropora acuminata (Randall, 1973a), Porites cocosensis (Randall and Eldredge, 1977), P. Compressa (Maragos, 1972), P. lobata (Dollar, 1975), Montastrea annularis (Jones, 1977), Goniopora stokesi (Rosen and Taylor, 1969; Sheppard, 1981), and the Fungiidae (Wells, 1966). Fragmentation and/or movement of fragments also results in (1) reef extension, (2) initiation of patch reef formation, (3) development of monospecific coral thickets in major reef zones, and (4) possibly avoidance of reef-bound competitors and predators.

The development of coral thickets, i.e. monospecific stands covering large areas on reefs (e.g. Fig. 3a) is of considerable importance. Thickets expand by the rapid growth of branches around the periphery. Many break and fall onto the surrounding substrate, covering or shading competitors and providing hard substrate for growth of other branches, or producing new branches of their own if they survive. This cascading of branches is a superior competitive mechanism resulting in the overgrowth and overtopping of other corals (Fig. 3c, d, e), even those individually dominant in direct aggression (Fig. 3f; Maragos, 1972; Connell, 1973; Shinn, 1976; Tunnicliffe, 1980). Development of coral thickets also provides habitats for a remarkable array of reef fishes, invertebrates, and algae (Talbot, 1965; Glynn, 1973; Grassle, 1973; Patton, 1976; Ogden and Ehrlich, 1977; Brock et al., 1979) although the diversity of primary space occupiers is reduced (Talbot, 1965). Since corals capable of forming thickets or monospecific stands tend to have high growth rates (e.g. Randall, 1973a), their domination of a reef or reef zone may result in very high rates of reef development. The highest rates of reef growth so far reported are for reefs dominated by Acropora cervicornis (Macintyre et al., 1977), A. palmata (Adey, 1975; Macintyre and

\footnotetext{
- Reef extension: Acropora spp. (Mergner, 1971), Montastrea annularis (Jones, 1977), Pocillopora damicornis (Glynn et al., 1972; Glynn and Macintyre, 1977; Glynn, in press; Wellington, 1981), Porites lutea (Highsmith, 1980a), Goniopora stokesi (Sheppard, 1981). Initiation of patch reef formation: Acropora cervicornis (Gilmore and Hall, 1976; Shinn, 1976), M. annularis (Smith and Tyler, 1975), Porites compressa (Maragos, 1972), P. lutea (Highsmith, 1980a), Fungiidae (Sheppard, 1981). Development of thickets: A. acuminata (Randall, 1973a), A. aspera (Randall, 1973a), A. attenuata (Sheppard, 1981), A. cervicornis (Gilmore and Hall, 1976; Shinn, 1976), A. formosa (Davies et al., 1971; Sheppard, 1981), A. hyacinthus (Sheppard, 1981), A. palmata (Goreau, 1959; Scatterday, 1974), A. spp. (Pichon, 1971; Rosen, 1971), Madracis mirabilis (Bonem and Stanley, 1977; Bak and Engel, 1979), Pocillopora damicornis (Glynn et al., 1972; Glynn and Macintyre, 1977), Porites compressa (Maragos, 1972), and the ahermatypic coral Lophelia pertusa (Wilson, 1979). Avoidance of competitors and predators (Sheppard, 1979; Highsmith, 1980a)
} 
Glynn, 1976), and Pocillopora damicornis (Glynn and Macintyre, 1977).

Further, fragmentation may play an important role in the rate at which coral reefs recover from hurricanes, which are exceedingly common over geologic time (see footnote, p. 210), or other disturbances. In some cases, reefs recover surprisingly fast, regaining their approximate pre-storm condition within 5 to 10 yr or less (Endean, 1973; Shinn, 1976). In other cases, where coral mortality was extremely high, recovery appears to require 2 decades or more. In 1961, for example, Hurricane Hattie destroyed $75-80 \%$ of the corals, including $100 \%$ of Acropora cervicornis, $80 \%$ of $\mathrm{A}$. palmata, and $50 \%$ of Montastrea annularis on a $50-60 \mathrm{~km}$ wide section of the Belize barrier reef (Stoddart, 1974). Four years after the storm, the only significant frame-building corals present were those which survived the storm ${ }^{\circ}$. By 1972 , some recruitment of A. palmata had occurred but $A$. cervicornis was still relatively uncommon. Areas farther from the center of the storm path had completely recovered by this time. Similarly, recovery of coral communities decimated by lava flows in Hawaii appears to require 20 to $50 \mathrm{yr}$ (Grigg and Maragos, 1974) and recovery of reefs at Guam where over $95 \%$ of the corals were killed by Acanthaster, may require 20 to 30 yr or longer (Randall, 1973b). Rapid recovery rates from storm damage have been attributed to the survival of coral fragments (Shinn, 1976; Highsmith et al., 1980). Slow recovery evidently occurs when a disturbance is so severe that hardly any fragments of the major reef-building corals survive. Thus, it appears that reefs recover rapidly when asexual reproduction and regeneration are possible but slowly when recovery depends upon sexual reproduction, probably reflecting high mortality rates for larvae and juveniles and possibly the low priority of sexual reproduction in the energy budgets of many corals (Table 8).

Survival of coral fragments may also facilitate recovery of reefs from dredging activities. On a dredged coral knoll at Diego Garcia, Sheppard (1980b) found many fragments and detached corals had survived. Subsequent growth of the corals frequently resulted in

\footnotetext{
- Recruitment had occurred among corals that Stoddart (1974) did not consider significant frame-builders: Agaricia, Millepora, Porites astreoides, Manicina areolata, Eusmilia fastigiata, and Mycetophillia lamarckana. I predict that life histories of these corals will be most similar to those of the species in the upper portion of Table 8. A agaricites is already listed and it is known that $M$. areolata has determinate growth resulting in small adult size (Goreau and Goreau, 1960). P. astreoides was the second most abundant species of juvenile coral at Bonaire and the third most abundant at Curacao (Bak and Engel. 1979) and does not attain large size (MacGeachy, 1977). Juveniles of Millepora and E. fastigiata were also relatively abundant at Curacao (Bak and Engel, 1979).
}

reattachment, contributing significantly to consolidation of the dredge-produced talus (Sheppard, 1980b).

Finally, if asexual reproduction by fragmentation is as extensive as indicated by the data presented above, then there must be considerably fewer genotypes (evolutionary individuals of Janzen, 1977) than actual colonies on coral reefs. There is no information available in the coral literature on this point but there have been several studies on plants that form extensive clones vegetatively. Populations of grasses (Harberd, 1962, 1967) and aspens (Kemperman and Barnes, 1976) tend to have very few genotypes, to dominate large areas, and to attain very great age, in agreement with predictions presented earlier for corals and suggesting that the predictions may be applicable to primaryspace occuppying organisms in general.

\section{CONCLUSIONS}

Fragments, because of their relatively large size, are not subject to the high mortality rates of larvae and juveniles. In addition to local distribution, including acquisition of space from other species and colonization of new habitats, a coral can theoretically achieve virtual immortality by spreading the risk of death over many long-lived individuals capable of subsequently producing fragments also. Sexual reproduction in these corals, which may be restricted to release of gametes during short periods, results in broader dispersal than would be possible with fragments, thus serving as a hedge against the entire clone being killed during large-scale disturbances such as hurricanes.

The evidence presently available suggests that fragmentation may be the predominant mode of reproduction for many of the major reef-building corals, i.e. those most important ecologically in terms of abundance, energy flow, competitive ability, and creation of habitat for other organisms, and geologically in terms of primary reef-frame construction, rate of reef growth, reef morphology, and recovery from disturbances.

Acknowledgements. Helpful discussion: G. Wellington, $H$. Lessios. Critical comments on the manuscript: S. Foster, P. W Glynn, S. Hoftman, A. J. Kohn, H. Lessios, R. G. Pearson, A. C. Riggs, M. Stouder, R. L. Trivers. Field assistance: I. Berzins, G. Middendorf, P. W Glynn, A. Velarde. Crew of the R. V Benjamin: J. Bryan, Master; L. Cruz, Mate; Carlos, Kuna guide. Typing: D. D. Highsmith. Financial support: Smithsonian Tropical Research Institute postdoctoral fellowship, NSF grant \# OCE76-21271. I am very grateful to each of the above and to the Kuna People for permitting scientific research to be conducted in the San Blas Islands 


\section{LITERATURE CITED}

Adey, W. H. (1975). The algal ridges and coral reefs of St. Croix. Atoll Res. Bull. 187: 1-67

Antonius, A. (1977). Coral mortality in reefs: a problem for science and management. Proc. 3rd. Int. Coral Reef Symp. 2: $617-623$

Bak, R. P. M. (1976). The growth of coral colonies and the importance of crustose coralline algae and burrowing sponges in relation with carbonate accumulation. Neth. J. Sea Res. 10: 285-337

Bak, R. P. M. (1977). Coral reefs and their zonation in the Netherlands Antilles. AAPG Studies in Geology 4: 3-16

Bak, R. P. M., Engel, M. S. (1979). Distribution, abundance and survival of juvenile hermatypic corals (Scleractinia) and the importance of life history strategies in the parent coral community. Mar. Biol. 54: 341-352

Bak, R. P. M., Luckhurst, B. E. (1980). Constancy and change in coral reef habitats along depth gradients at Curacao. Oecologia (Berl.) 47: 145-155

Ball, M., Shinn, E., Stockman, K. (1967). The geologic effects of Hurricane Donna in south Florida. J. Geol. 75: 583-597

Barnes, D. J. (1973). Growth in colonial scleractinians. Bull. mar Sci. 23: 280-298

Benayahu, Y., Loya, Y. (1977). Space partitioning by stony corals, soft corals and benthic algae on the coral reefs of the northern Gulf of Eilat (Red Sea). Helgoländer wiss. Meeresunters. 30: 362-383

Birkeland, C. (1977). The importance of rate of biomass accumulation in early successional stages of benthic communities to the survival of coral recruits. Proc. 3rd. Int. Coral Reef Symp. 1. 15-21

Birkeland, C., Grimm, G., Randall, R. H. (1979). Separation of age and colony size as factors influencing the growth rates of corals. Abstract. In: Krasnov, E. V. (ed.) Use and preservation of coral reef resources. XIV Pacific Science Congress, Khabarovsk, p. 18

Bonem, Z. M., Stanley, Jr., G. D. (1977). Zonation of lagoonal patch reef: analysis, comparison, and implications for fossil biohermal assemblages. Proc. 3rd Int. Coral Reef Symp. 2: $175-181$

Braithwaite, C. J. R. (1971). Seychelles reefs: structure and development. In: Stoddart, D. R., Yonge, C. M. (eds.) Regional variation in Indian Ocean coral reefs. Academic Press, London, pp. 39-42

Brandon, D. E. (1973). Waters of the Great Barrier Reef province. In: Jones, O. A., Endean, R. (eds.) Biology and geology of coral reefs. Vol. I, Geology 1. Academic Press, New York, pp. 187-232

Brock, R. E., Lewis, C., Wass, R. C. (1979). Stability and structure of a fish community on a coral patch reef in Hawaii. Mar. Biol. 54: 281-292

Brown, B. E., Dunne, R. P. (1980). Environmental controls of patch-reef growth and development. Mar. Biol. 56: 85-96

Chevalier, J. P. (1973). Coral reefs of New Caledonia. In: Jones, O. A., Endean, R. (eds.) Biology and geology of coral reefs. Vol. I, Geology 1. Academic Press, New York, pp. $143-167$

Chevalier, J. P. (1977). Origin of the reef formations of Moorea Island (Archipelago of la Societe). Proc. 3rd. Int. Coral Reef Symp. 2: 283-287

Cloud, P. E. (1959). Geology of Saipan, Mariana Islands, Pt. 4 Submarine topography and shoal-water ecology. Prof Pap. U.S. geol. Surv., No. 280-K, pp. 361-445

Connell, J. (1973). Population ecology of reef-building corals In: Jones, O. A., Endean, R. (eds.) Biology and geology of coral reefs. Vol. II, Biology 1. Academic Press, New York, pp. 205-245

Connell, J. (1976). Competitive interactions and the species diversity of corals. In: Mackie, G. E. (ed.) Coelenterate ecology and behavior Plenum, New York, pp. 51-58

Connell, J. (1978). Diversity in tropical rain forests and coral reefs. Science, N. Y 199: 1302-1310

Cook, R. E. (1979). Asexual reproduction: a farther consideration. Am. Nat. 113: 769-772

Dana, J. D. (1853). Coral reefs and islands, Putnam, New York

Davies, P. S., Stoddart, D. R., Sigee, D. C. (1971). Seychelles reefs: structure and development. Symp. Zool. Soc. Lond 28: 39-63

Ditlev, H. (1978). Zonation of corals (Scleractinia: Coelenterata) on intertidal reef flats at Ko-Phuket, eastern Indian Ocean. Mar. Biol. 47: 29-39

Dollar, S. (1975). Zonation of reef corals off the Kona coast of Hawaii, M.S. thesis, University of Hawaii, Honolulu

Duerden, J, E. (1902). Boring algae as agents in the disintegration of corals. Bull. Am. Mus. nat. Hist. 16: 323-332

Dunne, R. P., Brown, B. E. (1979). Some aspects of the ecology of reefs surrounding Anegada, British Virgin Islands. Atoll Res. Bull. 236: 1-80

Durham, J. W. (1966). Coelenterates, especially stony corals, from the Galapagos and Cocos Islands. In: Bowman, R. I. (ed.) The Galapagos. Univ. California, Berkeley, pp. $123-135$

Dustan, P. (1977). Vitality of reef coral populations off Key Largo, Florida: recruitment and mortality. Environ. Geol. 2: $51-58$

Edmondson, C. H. (1929). Growth of Hawaiian corals. Bull. Bernice P. Bishop Mus. 58: 1-38

Endean, R. (1973). Population explosions of Acanthaster planci and associated destruction of hermatypic corals in the Indo-West Pacific region. In: Jones, O. A., Endean, R (eds.) Biology and geology of coral reefs. Vol. II, Biology 1 Academic Press, New York, pp. 389-438

Focke, J. W. (1978). Holocene development of coral fringing reefs, leeward off Curacao and Bonaire (Netherlands Antilles). Mar, Geo]. 28: M31-M41

Gilmore, M. D., Hall, B. R. (1976). Life history, growth habits, and constructional roles of Acropora cervicornis in the patch reef environment. J. sedim. Petrol. 46: 519-522

Gladfelter, E. H., Monohan, R. K., Gladfelter, W B. (1978). Growth rates of five reef-building corals in the northeastern Caribbean. Bull. mar. Sci. 28: 728-732

Glesener, R. R., Tilman, D. (1978). Sexuality and the components of environmental uncertainty: clues from geographic parthenogenesis in terrestrial animals. Am. Nat. 112: 659-673

Glynn, P. W. (1973). Aspects of the ecology of coral reefs in the western Atlantic region. In: Jones, O. A., Endean, R. (eds.) Biology and geology of coral reefs. Vol. II, Biology 1 Academic Press, New York, pp. 271-324

Glynn, P. W. (1974). Rolling stones among the Scleractinia mobile corallith communities in the Gulf of Panama. Proc 2nd. Int. Coral Reef Symp. 2: 183-198

Glynn, P. W. (1976). Some physical and biological determi nants of coral community structure in the eastern Pacific Écol. Monogr. 46: 431-456

Glynn, P. W. (1977). Coral growth in upwelling and nonupwelling areas off the Pacific coast of Panama. J. mar Res. 35: 567-585

Glynn, P. W. (in press). Coral communities and their modifications relative to past and prospective Central American seaways. In: Advances in marine biology. Academic Press, London 
Glynn, P. W., Almodovar, L., Gonzales, J (1965). Effects of Hurricane Edith on marine life in La Parguera, Puerto Rico. Caribb. J. Sci. 4: 335-345

Glynn, P. W., Macintyre, I. G. (1977). Growth rate and age of coral reets on the Pacific coast of Panama. Proc. 3rd. Int. Coral Reef Symp. 2: 251-259

Glynn, P. W., Stewart, R., McCosker, J. (1972). Pacific coral reefs of Panama: structure, distribution and predators. Geol. Rundschau 61: 483-519

Glynn, P. W., Wellington, G. M., Birkeland, C. (1979). Coral reef growth in the Galápagos: limitation by sea urchins. Science, N. Y 203: 47-49

Goreau, T F. (1959). The ecology of Jamaican coral reefs I. Species composition and zonation. Ecology 40:67-90

Goreau, T F., Goreau, N. I. (1960). The physiology of skeleton formation in corals, III. Calcification rate as a function of colony weight and total nitrogen content in the reef coral Manicina areolata (Linnaeus). Biol. Bull. mar. biol. Lab., Woods Hole 118: 419-429

Goreau, T. F., Goreau, N. I. (1973). The ecology of Jamaican coral reefs. II. Geomorphology, zonation, and sedimentary phases. Bull. mar. Sci. 23: 399-464

Grassle, J. F. (1973). Variety in coral communities. In: Jones, O. A., Endean, R. (eds.) Biology and geology of coral reefs. Vol. II, Biology 1. Academic Press, New York, pp. 247-270

Grigg, R. W., Maragos, J. E. (1974). Recolonization of hermatypic corals on submerged lava flows in Hawaii. Ecology 55: $387-395$

Hada, $Y$ (1932). A note of the earlier stage of colony formation with the coral, Pocillopora caespitosa Dana. Scient. Rep. Tohoku imp. Univ. 4: 425-431

Harberd, D. J. (1962). Some observations on natural clones of Festuca ovina L. New Phytol. 61. 85-100

Harberd, D. J. (1967). Observations on natural clones of Holcus mallis. New Phytol. 66: 401-408

Harper, J. L. (1977). Population biology of plants, Academic Press, London

Harrigan, J. F. (1972). The planula larva of Pocillopora damicornis: lunar periodicity of swarming and substratum selection behavior Ph.D. thesis, Univ, of Hawaii, Honululu

Heck, K. L., McCoy, E. D. (1978). Long distance dispersal and the reef-building corals of the eastern Pacific. Mar Biol. 48: $349-356$

Hernandez-Avila, M. L., Roberts, H. H., Rouse, L. J. (1977). Hurricane generated waves and coastal boulder rampart formation. Proc. 3rd. Int. Coral Reef Symp. 2: 71-78

Highsmith, R. C. (1979). Coral growth rates and environmental control of density banding. J. exp. mar Biol. Ecol. 37 : 105-125

Highsmith, R. C. (1980a). Passive colonization and asexual colony mulitplication in the massive coral Porites luted Milne Edwards \& Haime. J. exp. mar. Biol. Ecol. 47: 55-67

Highsmith, R. C. (1980b). Geographic patterns of coral bioerosion: a productivity hypothesis. J. exp. mar. Biol. Ecol. 46 . $177-196$

Highsmith, R. C. (1981). Coral bioerosion at Enewetak: agents and dynamics. Int. Revue ges. Hydrobiol. 66: 335-375

Highsmith, R. C., Riggs, A. C., D'Antonio, C. M. (1980). Survival of hurricane-generated coral fragments and a disturbance model of reef calcification/growth rates Oecologia (Berl.) 46:322-329

Hughes, T. P., Jackson, J. B. C. (1980). Do corals lie about their age? Some demographic consequences of partial mortality, fission, and fusion. Science, N. Y. 209: 713-715

James, N. P., Ginsburg, R. N., Marszalek, D. S., Choquette, P W. (1976). Facies and fabric specificity of early subsea cements in shallow Belize (British Honduras) reefs. J sedim. Petrol. 46: 523-544

Janzen, D. H. (1977). What are dandelions and aphids? Am Nat. 111. 586-589

Jackson, J. B. C. (1979). Morphological strategies of sessile animals. In: Larwood, G., Rosen, B. R. (eds.) Biology and systematics of colonial organisms. Academic Press, New York, pp. 499-555

Jones, J. A. (1977). Morphology and development of southeastern Florida patch reefs. Proc. 3rd. Int. Coral Reef Symp. 2: 231-235

Kemperman, J. A., Barnes, B. V (1976). Clone size in American aspens. Can. J. Bot. 54: 2603-2607

Kissling, D. L. (1965). Coral distribution on a shoal in Spanish Harbor, Florida Keys. Bull mar. Sci. 15: 599-611

Lewis, J. B. (1960). The coral reefs and coral communities of Barbados, West Indies. Can. J. Zool. 38: 1133-1145

Lewis, J. B. (1974). Settlement and growth factors influencing the contagious distribution of some Atlantic reef corals. Proc. 2nd. Int. Coral Reef Symp. 2: 201-206

Lighty, R. G. (1977). Relict shelf-edge Holocene coral reef southeast coast of Florida. Proc. 3rd. Int. Coral Reef Symp. 2: $215-222$

Loya, Y (1976a). Skeletal regeneration in a Red Sea scleractinean coral population. Nature, Lond. 261: 490-491

Loya, Y (1976b). The Red Sea coral Stylophora pistillata is an r strategist. Nature, Lond. 259: 478-480

Loya, Y. (1976c). Settlement, mortality and recruitment of a Red Sea scleractinian coral population. In: Mackie, G. O. (ed.) Coelenterate ecology and behavior Plenum Press, New York, pp. 89-100

Loya, Y., Slobodkin, L. B. (1971). The coral reefs of Eilat (Gulf of Eilat, Red Sea). Symp. Zool. Soc. Lond. 28: 117-139

Ma, T. Y H. (1957). The effect of warm and cold currents in the southwestern Pacific on the growth rate of reef corals. Oceanographic Sinica 5: 1-34

MacGeachy, J. K. (1977). Factors controlling sponge boring in Barbados reef corals. Proc. 3rd. Int. Coral Reef Symp. 2 $477-483$

Macintyre, I. G., Burke, R. B., Stuckenrath, R. (1977). Thickest recorded Holocene reef section, Isla Perez core hole, Alacran Reef, Mexico. Geology 5: 749-754

Macintyre, I. G., Glynn, P. W (1976). Evolution of modern Caribbean fringing reef, Galeta Point, Panama. Am. Ass. Petrol. Geol. Bull. 60: 1054-1072

Maragos, J. (1972). A study of the ecology of Hawaiian reef corals. Ph.D thesis, Univ. of Hawail, Honolulu

Marion, M. (1883). Esquisse d'une topographie zoologique de Golfe de Marseille. Annls Hist. nat. Marseille (Zool.) 1 $1-108$

Marshall, S. M., Stephenson, T A. (1933). The breeding of reef animals, Part 1 The corals. Scient. Rep. Gt Barrier Reef Exped. 3: 219-245

Marszalek, D. S., Babashoff, Jr., G., Noel, M. R., Worley, D. R (1977). Reef distribution in south Florida. Proc. 3rd. Int. Coral Reef Symp. 2: 223-229

Maynard Smith, J. (1978). The evolution of sex, Cambridge Univ. Press, Cambridge

Mayor, A. G. (1918). Ecology of Murray Isd. coral reef. Pap. Dep. mar Biol. Carnegie Instn Wash. 9: 1-48

Mergner, H. (1971). Structure, ecology and zonation of Red Sea reefs. Symp. Zool. Soc. Lond. 28: 141-161

Mergner, H., Scheer, G. (1974). The physiographic zonation and the ecological conditions of some south Indian and Ceylon coral reefs. Proc. 2nd. Int. Coral Reef Symp. 2: 3-30 Mesolella, K. J. (1967). Zonation of uplifted Pleistocene coral 
reefs on Barbados, West Indies. Science, N.Y 156: $638-640$

Milliman, J. D. (1973). Caribbean coral reefs. In: Jones, O. A., Endean, R. (eds.) Biology and geology of coral reefs. Vol. I, Geology 1. Academic Press, New York, pp. 1-50

Motoda, S. (1939). Submarine illumination, silt content, and quantity of food plankton of reef corals in Iwayama Bay, Palao. Palao trop. biol. Stn Stud. 1: 637-650

Ogden, J. C., Ehrlich, P. R. (1977). The behavior of heterotypic resting schools of juvenile grunts (Pomadasyidae). Mar Biol. 42: 273-280

Orme, G. R. (1977). Aspects of sedimentation in the coral reef environment. In: Jones, O. A., Endean, R. (eds.) Biology and geology of coral reefs, Vol. IV, Geology 2. Academic Press, New York, pp. 129-182

Patton, W. K. (1976). Animal associates of living reef corals. In: Jones, O. A., Endean, R. (eds.) Biology and geology of coral reefs, Vol. III, Biology 2. Academic Press, New York, pp. $1-36$

Pearse, V B., Muscatine, L. (1971). Role of symbiotic algae (Zooxanthellae) in coral calcification. Biol. Bull. mar. biol. Lab., Woods Hole 141: 350-363

Perkins, R., Enos, P. (1968). Hurricane Betsy in the FloridaBahama area-geologic effects and comparison with Hurricane Donna. J. Geol. 76: 710-717

Pichon, M. (1971). Comparative study of the main features of some coral reefs of Madagascar, La Reunion and Mauritius. Symp. zool. Soc. Lond. 28: 185-216

Pichon, M. (1977). Physiography, morphology and ecology of the double barrier reef of North Bohol (Philippines). Proc. 3rd. Int. Coral Reef Symp. 2: 261-267

Porter, J. W. (1972). Ecology and species diversity of coral reefs on opposite sides of the Isthmus of Panama. Bull. Biol. Soc. Wash. 2: 89-116

Purdy, E. G. (1974). Reef configurations: cause and effect. In: Laporte, L. F. (ed.) Reefs in time and space. Soc. Econ. Paleontol. Mineral. Spec. Publ. 18: 9-76

Randall, R. H. (1973a). Reef physiography and distribution of corals at Tumon Bay, Guam, before Crown-of-Thorns starfish Acanthaster planci (L.) predation. Micronesica 9: $119-158$

Randall, R. H. (1973b). Coral reef recovery following extensive damage by the Crown-of-Thorns starfish, Acanthaster planci (L.). Publ. Seto mar biol. Lab. 20: 469-489

Randall, R., Eldredge, L. (1977). Effects of Typhoon Pamela on the coral reefs of Guam. Proc. 3rd Int. Coral Reef Symp. 2: 525-531

Rinkevich, B., Loya, Y (1979a). The reproduction of the Red Sea coral Stylophora pistillata. I. Gonads and planulae. Mar. Ecol. Prog. Ser. 1: 133-144

Rinkevich, B., Loya, Y (1979b). The reproduction of the Red Sea coral Sylophora pistillata. II. Synchronization in breeding and seasonality of planulae shedding. Mar. Ecol. Prog. Ser 1: 145-152

Rogers, C. S. (1979). The productivity of San Cristobal Reef, Puerto Rico. Limnol. Oceanogr. 24: 342-349

Rosen, B. R. (1971). Principal features of reef coral ecology in shallow water environments Mahé, Seychelles. Symp. zool. Soc. Lond. 28: 163-183

Rosen, B. R., Taylor, J. D. (1969). Reef coral from Aldabra: new mode of reproduction. Science, N. Y. 166: 119-121

Salvat, B., Richard, G., Toffart, J. L., Ricard, M., Galzin, R. (1977). Reef lagoon complex of Lakeba Island (Lau Group, Fiji): geomorphology, biotic associations and socio-ecology. Proc. 3rd. Int. Coral Reef Symp. 2: 297-303
Sammarco, P. W. (1980). Diadema and its relationship to coral spat mortality: grazing, competition, and biological disturbance. J. exp. mar. Biol. Ecol. 45: 245-272

Scatterday, J. (1974). Reefs and associated coral assemblages off Bonaire, Netherlands Antilles, and their bearing on Pleistocene and Recent reef models. Proc. 2nd. Int. Coral Reef Symp. 2: 85-106

Scatterday, J. (1977). Low-water emergence of Caribbean reefs and effect of exposure on coral diversity - observations off Bonaire, Netherlands Antilles. AAPG Studies in Geology 4: 155-169

Schuhmacher, H. (1974). On the conditions accompanying the first settlement of corals on artificial reefs with special reference to the influence of grazing sea urchins (Eilat, Red Sea). Proc. 2nd. Int. Coral Reef Symp. 1: 257-267

Schuhmacher, H. (1977). Initial phases in reef development, studied at artificial reef types off Eilat (Red Sea). Helgoländer wiss. Meeresunters. 30: 400-411

Scoffin, T P. (1977). Sea-level features on reefs in the northern province of the Great Barrier Reef. Proc. 3rd. Int. Coral Reef Symp. 2: 319-324

Scoffin, T. P., Stoddart, D. R. (1978). The nature and significance of microatolls. Phil. Trans. R. Soc. Lond., Ser. B 284: 99-122

Sheppard, C. R. C. (1979). Interspecific aggression between reef corals with reference to their distribution. Mar. Ecol. Prog. Ser 1: 237-247

Sheppard, C. R. C. (1980a). Coral cover, zonation and diversity on reef slopes of Chagos atolls, and population structures of the major species. Mar. Ecol. Prog. Ser. 2: 193-205

Sheppard, C. R. C. (1980b). Coral fauna of Diego Garcia lagoon following harbor construction. Mar. Pollut. Bull. 11. $227-230$

Sheppard, C. R. C. (1981). The reef and soft-substrate coral fauna of Chagos, Indian Ocean. J. nat. Hist. 15: 607-621

Shinn, E. (1976). Coral reef recovery in Florida and the Persian Gulf. Environ. Geol. 1: 241-254

Smith, C. L., Tyler, J. C. (1975). Succession and stability in fish communities of dome-shaped patch reefs in the West Indies. Am. Mus. Novit. 2572: 1-18

Squires, D. F. (1959). Results of the Puritan-American Museum of Natural History Expedition to western Mexico. 7. Corals and coral reefs in the Gulf of California. Bull Am. Mus. nat. Hist. 118: 371-431

Stephenson, T (1931). Development and formation of colonies in Pocillopora and Porites. Scient. Rep. Gt Barrier Reef Exped. 1: 113-134

Stephenson, T., Stephenson, A. (1933). Growth and asexual reproduction in corals. Scient. Rep. Gt Barrier Reef Exped 3: $167-217$

Stephenson, W., Endean, R., Bennett, I. (1958). An ecological survey of the marine fauna of Low Isles, Queensland. Austral. J. mar. Freshwat. Res. 9: 261-318

Stimson, J. S. (1976). Reproduction of some common Hawaiian reef corals. In: Mackie, G. O. (ed.) Coelenterate ecology and behavior. Plenum Press, New York, pp. $271-279$

Stimson, J. S. (1978). Mode and timing of reproduction in some common hermatypic corals of Hawaii and Enewetak Mar. Biol. 48: 173-184

Stoddart, D. R. (1963). Effects of Hurricane Hattie on the British Honduras reefs and cays, Oct. 30-31, 1961 Atoll Res. Bull. 95: 1-142

Stoddart, D. R. (1971). Environment and history in Indian Ocean reef morphology. Symp. zool. Soc. Lond. 28: 3-38

Stoddart, D. R. (1973). Coral reefs of the Indian Ocean. In: 
Jones, O. A., Endean, R. (eds.) Biology and geology of corals reefs. Vol. I, Geology 1 Academic, New York, pp. $51-92$

Stoddart, D. R. (1974). Post-hurricane changes on the British Honduras reefs: resurvey of 1972. Proc. 2nd. Int. Coral Reef Symp. 2: 473-483

Storr, J. F. (1964). Ecology and oceanography of the coral-reef tract, Abaco Island, Bahamas. Geol. Soc. Am. Spec. Bull. 79: $1-98$

Talbot, F. (1965). A description of the coral structure of Tutia Reef (Tanganyika Territory, East Africa), and its fish fauna. Proc. Zool. Soc. Lond. 145: 431-470

Taylor, D. L. (1977). Intra-colonial transport of organic compounds and calcium in some Atlantic reef corals. Proc. 3rd. Int. Coral Reef Symp. 1: 431-436

Tunnicliffe, V. (1978). The role of boring sponges in coral fracture. In: Levi. C., Boury-Esnault, N. (eds.) Biologie des Spongiaires. Centre National de la Recherche Scientifique, Paris, pp. 309-315

Tunnicliffe, $V$ (1980). Biological and physical processes affecting the survival of a stony coral, Acropora cervicor- nis. Ph.D. thesis, Yale University, New Haven

Vaughn, T W. (1909). Geology of the Keys, the marine bottom deposits and recent corals of southern Florida. Yb. Carnegle Instn Wash. 8: 140-144

Vicente, V. P. (1978). An ecological evaluation of the West Indian demosponge Anthosigmella varians (Hadromerida: Spirastrellidae). Bull. mar. Sci. 28: 771-777

Wellington, G. M. (1981). The role of competition, niche diversification and predation on the structure and organization of a fringing coral reef in the Gulf of Panama. Ph.D. thesis, Univ. of California, Santa Barbara

Wells, J. W. (1954). Recent corals of the Marshall Islands. Prof. Pap. U.S. Geol. Surv. 260-I: 385-486

Wells, J. W. (1966). Evolutionary development in the scleractinian family Fungiidae. In: Rees, W. J. (ed.) The Cnidaria and their evolution. Academic Press, London, pp. 223-246

Williams, G. C. (1975). Sex and evolution, Princeton Univ. Press, Princeton

Wilson, J. B. (1979). 'Patch' development of the deep-water coral Lophelia pertusa (L.) on Rockall Bank. J. mar. biol. Ass. U.K. 59: 165-177

This review was submitted to the editor; it was accepted for printing on September 13, 1981 


\section{Erratum}

Re: Highsmith, Mar. Ecol. Prog. Ser. 7: 207-226, 1982

- Replace Table 6 on p. 215 as follows:

Table 6 Porites furcata. Substrate attachment relative to position within or adjacent to dense patches of the coral. Clump: colony located within the patch surtounded by other $P$ furcata, edge edge of patch; hole: hole within or adjacent to the patch (see Fig 2d); other: corals of other species or coral debns; altached connected to substratum, detached. not connected to substratum; loose: stem broken but supported in growth position by neighboring colonjes Values expected by $X^{2}$ test are shown in parentheses

\begin{tabular}{|c|c|c|c|c|c|c|c|}
\hline Location & Position & Altachedl & Detached & Loose. & Dead & Other & Total. \\
\hline \multirow[t]{4}{*}{ Actutupo } & Clump & $\begin{array}{l}151 \\
(116)\end{array}$ & $\begin{array}{c}8 \\
(138)\end{array}$ & $\begin{array}{l}437 \\
\{250\}\end{array}$ & 20 & 7 & 623 \\
\hline & Edge & $\begin{array}{r}18 \\
(22)\end{array}$ & $\begin{array}{r}52 \\
(26)\end{array}$ & $\begin{array}{l}42 \\
4641\end{array}$ & 25 & 11 & 148 \\
\hline & Hole & $\begin{array}{c}\mathrm{a} \\
(39)\end{array}$ & $\begin{array}{l}150 \\
(46)\end{array}$ & $\begin{array}{r}42 \\
(115)\end{array}$ & 295 & 324 & 819 \\
\hline & Other & & & 1 & & 47 & 48 \\
\hline \multirow[t]{4}{*}{ Bugatupo } & Clump & $\begin{array}{l}166 \\
\{129\}\end{array}$ & (157) & $\begin{array}{c}529 \\
(413)\end{array}$ & 27 & 10 & 737 \\
\hline & Eage & (19) & $\begin{array}{r}49 \\
(23)\end{array}$ & $\begin{array}{c}49 \\
(60)\end{array}$ & 7 & 11 & 120 \\
\hline & Hole & $\begin{array}{l}19 \\
\text { (41) }\end{array}$ & $\begin{array}{l}176 \\
(50)\end{array}$ & $\begin{array}{c}26 \\
(130)\end{array}$ & 202 & 290 & 713 \\
\hline & Other & & & & & 68 & 68 \\
\hline \multirow[t]{5}{*}{ Setlar } & Clump & $\begin{array}{l}165 \\
(133)\end{array}$ & (107) & $\begin{array}{c}371 \\
(292)\end{array}$ & 20 & 14 & 579 \\
\hline & Edge & $\begin{array}{r}12 \\
1221\end{array}$ & $\begin{array}{c}38 \\
(20)\end{array}$ & $\begin{array}{c}40 \\
\text { (48) }\end{array}$ & 1 & 13 & 104 \\
\hline & Hole & $\begin{array}{l}23 \\
(45)\end{array}$ & $\begin{array}{l}133 \\
(40)\end{array}$ & $\begin{array}{c}28 \\
(99)\end{array}$ & 68 & 525 & 777 \\
\hline & Other & 1 & & 1 & & 176 & 178 \\
\hline & Total & 567 & 620 & 1566 & 665 & 1496 & 4914 \\
\hline
\end{tabular}

